\title{
Causes of Biodiversity Depletion in Bangladesh and Their Consequences on Ecosystem Services
}

\author{
Md. Redwanur Rahman \\ Ecology and Biodiversity Research Laboratary, Institute of Environmental Science, University of Rajshahi, Rajshahi, Bangladesh
}

Email address:

redwan_rahman@1ycos.com

\section{To cite this article:}

Md. Redwanur Rahman. Causes of Biodiversity Depletion in Bangladesh and Their Consequences on Ecosystem Services. American Journal of Environmental Protection. Vol. 4, No. 5, 2015, pp. 214-236. doi: 10.11648/j.ajep.20150405.13

\begin{abstract}
Bangladesh is exceptionally endowed with a vast variety of flora and fauna due to its unique geophysical location which are maintaining balance ecosystem. There are recorded 5,700 angiosperms, 68 legumes, 500 medicinal plants, 29 orchids and 1,700 pteridophytes. Sundarban is a rich faunal diversity in Bangladesh which mammals 113, birds 628, reptiles 126, amphibians 22, 708 fishes, insects 2,493, mites 19, alges 164 and 4 species of echinoderms. Bangladesh's inland water bodies are known to be the habitat of 266 species of indigenous fish, 13 exotic fish, 56 prawns, about 26 freshwater molluscs, and 150 birds. The marine water bodies (200 nautical miles along the coast) are also remarkable for being habitat of 442 species of fish. There are at least 36 species of marine shrimps. About 336 species of molluscs, covering 151 genera have been identified from the Bay of Bengal. In addition, several species of crabs, and 31 species of turtles and tortoises, of which 24 live in freshwater, are found in Bangladesh. A total of 168 seaweeds, 3 sponges, 15 crabs, 3 lobsters, 10 frogs, 3 crocodiles, 24 snakes, 3 otters, 1porcupine, 9 dolphins, and 3 species of whale found in Bangladesh. About 70 bees, many species of wasps and 8-10 per cent of the land area is under good canopy cover. A total of 81 fish species were recorded from Chalan Beel including 72 indigenous fish species and nine exotic species. More than 85 percent of Modhupur forest has been cleared in last 40 years. In most of the areas the age of sal forest is not more than 10 to 15 years. Thousands prawn farms have replaced almost the Chokoria mangrove forest. Thousands prawn farms have replaced almost the entire forest. The Chokoria Sundarbans today- the evergreen forests have been replaced by thousands of shrimp ponds. Two orders of class Oligochaeta of phylum Annelida: five families, nine genera include fifteen species of Tangail District of Bangladesh. A total of 35 species of earthworms have been recorded in Bangladesh. Already, 12 wildlife species have become extinct from Bangladesh. In addition, Mammals 40, birds 41, reptiles 58 and amphibians 8 have listed in red data book of threatened animals of Bangladesh. Anthropogenic pressures, uncontrolled dredging, hydrological intervention, pollution, chemical fertilizers are directly effect on habitat, biodiversity and aquifer. In this article, the causes of depletion of biodiversity and the consequences on ecosystem services were observed.
\end{abstract}

Keywords: Biodiversity, Depletion, Consequences, Ecosystem, Bangladesh

\section{Introduction}

"Biological Diversity" means the variability among living organisms from all sources including, inter alia, terrestrial, marine and other aquatic ecosystems, and the ecological complexes of which they are part; it includes diversity within species between species, and of ecosystems (Article II, CBD, 1992). Literal meaning of biodiversity is the diversity of all life forms on earth. This includes the various races and species of all microbes, plants, and animals that live on earth, including their genetic differences, i.e., the gene pool of each species. Bangladesh is a transitional zone of flora and fauna, because of its geographical settings and climatic characteristics. As mentioned in the overview section of the report that there are many rivers and streams existing in the country covering a length of $22,155 \mathrm{~km}$. In addition to the regular inland waters, seasonally a large part of the country remains submerged for 3-4 months during monsoon. This country is rich in fish and aquatic resources, and other biodiversity [1]. Sundarban is a largest mangrove forest in the world. It is located in between $21^{\circ} 32^{\prime}-21^{\circ} 55^{\prime} \mathrm{N}$ latitude and between $88^{\circ} 42^{\prime}-89^{\circ} 04^{\prime} \mathrm{E}$ longitude and $7.5 \mathrm{~m}$ above sea level. The forest densely covered by sundary (Heritiera littoralis) tree. It is also largest reserve for the Royal Bengal Tiger (Panthera tigiris) in the world. [1,2] has 
reported that Bangladesh is exceptionally endowed with a vast variety of flora and fauna due to its unique geophysical location. [3] recorded 5,700 angiosperms species from sundarbans. They also recorded 68 legumes, 500 medicinal plants, 29 orchids and 1,700 pteridophytes from these mangrove forests. Sundarban is a rich faunal diversity in Bangladesh which mammals 113, birds 628, reptiles 126 , amphibians 22, 708 fishes (fresh, estuarine and marine), insects 2,493, mites 19, alges 164 and echinoderms 4 species were found in Sundarban $[3,4]$. Like in other regions around the globe, the biodiversity of Bangladesh is also entering through a critical period. [5] has shown that already, 12 wildlife species have become extinct from Bangladesh. In addition, Mammals 40, birds 41, reptiles 58 and amphibians 8 have listed in red data book of threatened animals of Bangladesh [4]. On the other side, 106 vascular plants under risk of various degree for extinction of Bangladesh [6].

Some of the important relevant literatures about biodiversity in Bangladesh are discussed here. [7] has published an article on Biodiversity Conservation Strategies in Bangladesh: the state of protected areas. He find out some major causes as, rural poverty, ignoring local people, illegal wood extraction, overexploitation, poor forest management, lack of trained personnel and awareness about biodiversity. [8] has published that there is no legal issue related to environment and contains vast information about the affection of human lives by environment and environmental science every day. [9] has published that related to environment as a fusion of theory, basic research, applied research and public education, that is evolving at a peace. Land includes agriculture, irrigation etc., to the study. The writer did not deal with all agriculture and fisheries laws and policies in the light of environmental aspects prevailing in the country.

[10] has recorded a report on the environmental attempts to tell signs of the time with regard to our environment, resources and people of Bangladesh. [11] reported that the biological diversity are rapidly destroying the environments from more than billion years. [12] has described that there is no law resolution nevertheless this book is very important for having informative discussion about extinct wildlife. A complete particulars and solution of some controversial concept about the extinct wildlife are found in this book with information of the studies both nationally and internationally. [13] has mentioned that about the contribution of wildlife with a view to making the people conscious and it is riched with root level information related to wildlife management of Bangladesh. [14] has contributed that the development of our environmental studies from the different grounds. [15] has analysed that about the present and past status of Bangladesh.

The sundarban mangrove forest on the Bay of Bangle formed by Ganges, Brahmaputra and Meghna rivers across the southern part of Bangladesh. According to view point of English Writer Hunter, Sundarbon is erapted in the largest coastal area Hugli to Meghna which is about 81 miles [23]. It is a swamp forest which covers $10,000 \mathrm{sq}$. $\mathrm{km}$. of which 6,017 sq.m in Bangladesh. The UNESCO in 1997 declared a world heritage as the sundarban. This forest is occupied by $1,874 \mathrm{sq}$. $\mathrm{km}$ water bodies forms of rivers and canals.

Royal Bengal Tiger (Panthera tigiris), birds, spotted deer, crocodiles and snakes etc are abundant in Sundarban. Fertile soils have been mostly converted to intensive agriculture. Population pressure, habitat loss, pollution, and poaching are putting tremendous pressures on the existing biodiversity. If the current trend continues, many of the species will be endangered or be even extinct. In case of 'Chalan beel" these percentage of lost is near about $3 \%$. The condition of wetlands is even worse than that of forests. Most of the wetlands are being converted into agriculture land and degraded due to development activities.

Throughout the world ecosystems today are threatened with destruction at a rate rarely seen in history. As a result depletion of biodiversity and climate change has gained the foremost importance in the current world order.

But unfortunately, many plant and animal species on Earth are facing severe threats to their survival and are disappearing at alarming rates. And human actions are the cause behind this biological degradation.

Bangladesh is no different story. Here environmental degradation is also severe. But this report will only focus on the Modhupur forest which is one of the oldest forests in this region i.e. last deciduous forest in Bangladesh. It was a vast resource of flora, fauna and natural resources. The ecosystem of the forest was very old. But from late 1980's, there have been implemented a number of government and foreign funded projects which cause felling of old diversified species of natural trees and replace them with monotonic exotic trees like rubber, acacia, eucalyptus, mahogany etc. which was planted for short term economic benefits. But these practices have adverse effects on biodiversity and ecosystem resulted in destroying several species of flora and fauna for good. As a result, the forest has been shrunken and the livelihood of people depend on forest has also been affected.

\section{Objectives of this chapter}

The objectives of the article are as follows:

i. to estimate the present scenario of biodiversity in Bangladesh;

ii. to identify the causes of depletion of biodiversity;

iii. to observe the consequences on Ecosystem Services and

iv. to prepare a set of recommendations that will enunciate the methods of integrating environmental change adaptation into various national actions focused on issues related to eco-zone management.

\section{Materials and Methods}

This research based on two sources such as primary and secondary source.

Primary Sources: The primary data has been collected through two methods, these are:

- Interview method and

- Field survey with prepared questionnaire

- Interview Method 
A pilot survey has been conducted to know the biodiversity depletion in Bangladesh and their consequences on ecosystem services. Primary problems are noticed in this time and then a detail survey with details questionnaire has been conducted. The mental condition, cordiality, willingness, transparency and patience of the respondents are being considered during interview. Because it is important to know the mentality of the respondents it either is positive or not while getting information. The respondents are selected from the head of household based on proportional allocation of stratified random sampling method.

- Field Survey with questionnaire

Data has been also colleted through field survey with a questionnaire to know the real feature of biodiversity condition of the study area. The questionnaire covers all the relevant questions to get the maximum information about the research topic. The authenticity of the data is justified through proper scrutiny. In this regard, cooperation has taken from local peoples.

\section{Secondary Source}

It includes related books, national and international journals, Reports, records, publications, government and non-governmental documents, published dissertations, internet, homepage, Bangladesh Statistical Bureau report, from different Institutes and offices etc.

The completed research prepared a cross sectional descriptive study. In this work qualitative data collected. Findings of the research presented in an analytical description.

Sample Size and Selection Procedure

Sampling procedure plays an important role of a research. It provides good information about diversity. A sample is a finite part of a statistical population whose properties are studied to gain information about the whole [32].

Methodology for Biodiversity Assessment in Sunderbans

The Sundarban Reserve Forest is situated at the southern part of Khulna, Bagerhat and Satkhira civil district lying in between latitude $21^{\circ} 27^{\prime} 30^{\prime \prime}$ and $22^{\circ} 30^{\prime} 00^{\prime \prime}$ North longitude $89^{\circ} 02^{\prime} 00^{\prime \prime}$ and $90^{\circ} 00^{\prime} 00^{\prime \prime}$ East. Sundarbans is under the administrative of Khulna, Satkhira and Bagerhat districts.
This case study has been conducted primarily based on the field visit in order to collect raw information from the field, also to get proper understanding and insight in the subject. Along with it, we had to depend on the source of information so that historical analysis and comparison can be made and a suggestive attitude can be developed.

To collect the information we have gone through literature stock from Bangladesh Statistical Bauru, Bangladesh Development Studies and other necessary documents found in other sources. After all, documents collection has also been relied on the internet.

\section{Methodology of Chalan beel Observation}

Required data were collected by side observation and interviewing the local people. There is no any specified or appropriate analytical method was used to analyze the collected environmental data. So collected data were tabulated and arranged, according to the researcher choice for achieving the objectives of the study.

\section{Results and Discussion}

The number of local varieties of varieties crops is steadily declining due to 'the Promotion and economic consideration of only a few selected varieties, especially of the High Yeld Varities (HYV) of rice and wheat and other crops. This is causing of irreparable loss to the genetic diversity of our crop plants and their wild relatives. Introduction of exotic carnivorous fishes like African perch and the African catfish poise a threat to the propagation of many indigenous fishes. It is now a concerned issue in Bangladesh which should take in consideration immediately. There are three prime reasons for which this critical situation has been raised in Bangladesh. These are: i. the lack of adequate conservation efforts to maintain and protect indigenous crop genetic recourses. ii. lack of software for the conservation and propagation of the various local crop varieties. iii. unbalanced competition between the local varieties consequent to the introduction, adoption and promotion of the exotic and locally developed HY varieties.

Table 1. Extinct wildlife in Bangladesh. According to [12]).

\begin{tabular}{llll}
\hline English Name & Scientific Name & English Name & Scientific Name \\
\hline Mammals & & & \\
Striped Hyena & Hyaena hyaena & Wolf & Canis lupus \\
Malayan sun Bear & Helorctos malayanus & Great one Horned Rhinoceros & $\begin{array}{l}\text { Rhinoceros unicornis } \\
\text { Smaller One Horned Rhinoceros }\end{array}$ \\
Asiatic Gaur & Rhinoceros sondaicus & Two Horned Rhinoceros & Dicerohinus sumatrensis \\
Wild Buffalo & Bos frontalis & Banteng & Bos javanicus \\
Bulebull & Bubalus bubalis & Black buck & Antelope cervicapra \\
Pygmy Hog & Bocehpalus tragocamelus & Swamp Deer/Barasingha & Cervus duvauceli \\
Birds & Sus salvinus & & \\
Bengal pinkheaded Dock & & & Pavo cristatus \\
Bengal Florican & Rhodonessa caryophyllacea & Indian Peafowl & Pavo muticus spicifer \\
Painted Stork & Eupodotis bengalensis & Green Peafowl & Leptoptilos dubius \\
King Vulture & Mycteria leucocephala & Greater Adjutant & \\
Reptiles & Sarcogyps calvus & & Trionyx nigricans \\
Indian Egg eating snake & & Chittagong Mud Turtle & \\
\hline
\end{tabular}


Table 2. Extinct plants species in Bangladesh. According to [15].

\begin{tabular}{llll}
\hline Scientific Name & Scientific Name & Scientific Name & Scientific Name \\
\hline Psilotum triquetrum & Tectaria chattagramica & Aglaonema clarki & Aldrovanda vesiculosa \\
Aquillaria agallacha & Cirrhopetalum roxburghii & Cymbopogon osmastonii & Debregeasia dentata \\
Elaeocarpus lucidus & Hippocratea macrantha & Homulium schlchtii Kurz & Limnophila cana \\
Mantisia spathulata & Marsdenia thyrsiflora & Ophiorrhiza villosa & Phrynium imbricatum \\
Quercus acuminate & Rotala sin pliciuscula & Semecarpus subpanduriformis & Sonneratia griffithii \\
Tournefortia roxburghii & Typhonium listeri & Vatica scapula & Justicia oreophila \\
Knema bengalensis & Vernonina Thomsoni & & \\
\hline
\end{tabular}

The population of domestic animals and birds of Bangladesh is insufficient to meet the basic minimum requirements of draft power, meat, milk and eggs. The total number of cattle was estimated at about 2.5 million sheep and goat 14.5 million, poultry 76.5 million heads after 198384 agricultural censuses. [16] has shown that the resources base declined steadily since the 40 s consequent to the human explosion in Bangladesh.

In addition, Bangladesh is a rich flora and faunal zone. All over the country, 22 amphibians, 400 fishes, 126 reptiles, 628 birds, 113 mammals were identified. Approximately, 5700 species of angiosperms were recorded in Bangladesh [4]. Extinct wildlife and plants in Bangladesh are presented in table 1 and 2.

Causes of Biodiversity Depletion in Bangladesh

Many wildlife species have been exterminated in Bangladesh and many more are threatened with extinction. The list of extinct animals of Bangladesh is prepared on the basis of published data and habitat management. The country has lost $10 \%$ of its mammalian fauna, $3 \%$ avifauna and $4 \%$ reptiles over the last 180 years. More than 50 species are critically endangered in Bangladesh of which 23 species are already declared as endangered in the Red Data Book of IUCN (International Union for Conservation of Nature). In addition, 83 species are threatened and are included in the appendices of Convention on International Trade in Endangered Species (CITES). Among them the most endangered species are : Elephant (Elephas maximus), Tiger (Panthera tigris), Wildcat (Felis chaus), Leopard (Panthera pardus), Dolphin (Peponocephala electra), among mammals; Whitling duck (Cairina scutulata), Knobbilled duck (Sarkidiornis melanotos), Black partridge (Perdicula manipurensis), among birds and Crocodile (Crocodylus, porosus) Python (Python molurus), Monitor (Varanus bengalensis), River Terrapin (Batagur baska), Roffed turtle (Kachuga dhongoka), Softshell turtle (Chitra punctata) and all marine turtle among reptiles. Bird population around the globe is declining at an alarming rate; the primary threats to them are habitat destruction, trade and over hunting [8, 10-22].

Despite the depletion of rivers, canal and flood plains for hundreds of year, Bangladesh still holds the worlds most diverse and abundant inland fisheries. But the catch of many popular local species have drastically reduced and many are no more seen. The fishes face many obstructions and disturbs in the reproduction period for the causes of unplanned construction in the flood plain area. Mistakenly, subsistence fishermen are often blamed for over fishing and thus reducing the fish population.
But the studies and expert opinions do not affirm this blame. The physical loss, shrinkage and modification of aquatic habitats for fish, prawn, turtle and other aquatic organizing are said to be one major factor in depleting the fish varieties.

Grazing, Illegal filling, fuel wood collection uncontrolled and wasteful commercial exploitation are also shown to be causes of depletion of forest resources, with drastically reduced forest, diminishing also are rare wildlife and Biological diversity.

\section{Reasons of Depletion of Biodiversity}

Bangladesh is rich flora and fauna diversity which are maintaining balance ecosystem. Presently, biodiversity is affecting due to deforestation, forest exploitations, agriculture and industrial pollution, irrigation and flood control developments, shifting land use and over exploitation of biological resources. Besides, Human beings occupy almost all the earthly land; therefore, the habitats of other lives are seriously hampered.

Human interference for agriculture and settlement such as flood control embankments, drainage systems and conversion of inundated lands into crop land have reduced the water area, prevented or altered the seasonal migratory routes of many fishes and reduced breeding and natural stocking of fishes in many water bodies.

We are facing serious environmental degradation due to unplanned development work and urbanization. Some major causes are as follows:

- Unsustainable use of Natural Resources

- Hill Clearing, Cutting and Destruction

- Industrial and Agro-Chemical Pollution

- Deforestation

- Illegal Hunting

- Habitats Degradation and Destruction

- Wetland Degradation

- Traditional Management and Short Sighted Development Efforts

- Introduction of Modern Agro-Technology

- Rapidly Expanding and Heavy Population Pressure

- Indiscriminate Filling of Trees and thereby reducing tree cover

- Over-exploitation of Particular Species, like Medicinal Plants, Bamboo, canes etc.

- Salinity Intrusion due to Reduced Freshwater flow in the Ganges and its Tributaries is affecting the Vegetation of the Sundarbans

- Destruction of the Mangrove forest of Chakaria and Teknaf for Conversion into Shrimp Culture 
- Frequent Occurrences of Natural Disasters, like Floods Droughts, Storms, Cyclones, Tornadoes, Tidal Surges etc.,

- Industrial, Domestic, Agro-Chemical and other Pollution an Irrational use of Chemical Fertilizers and Pesticides,

- Rapid, Unplanned and Uncontrolled Industrialization and Urbanization

- Changing the Character of the Land and Conversion of Low-lying areas to Build up Areas

- Construction of Upland Roads and Homesteads on Wetland

- Increased Salinity Intrusion in the Coastal areas due Lower Flow in the dry Season

- Pollution from Domestic and Agro-Chemical Waste Products and their runoff

- Hunting, Trapping and Disturbances of Animals

- Management of open water Fisheries Through Auction; Ineffective Legal Measures for the Protection of Undersize Fish

- Lack of Adequate Conservation Efforts to Maintain and Protect Indigenous Crop Genetic Resources

- Lack of Software for the Conservation and Propagation of the Various Local Crop Varieties

- Imbalanced Competition Between the Local Varieties Consequent to the Introduction, Adoption, and Promotion of the Exotic and Locally Developed High Yield Varieties (HYV)

- Gradual Encroachment of the Fallow Grazing Lands for Agricultural Crops and thereby reducing the base for Grass and Fodder Crops

- Regular, Almost Annual, Recurrence of Epizootic Diseases of Cattle and Poultry in some Parts of the Country

- Absence of Trained Manpower, Software and Logistic Support to Contain and Prevent such Recurrent Epizootic

- Long Absence of any Concern for the Production of Fodder Crop and Animal Feed in the Country, Even to the Extent of Exporting Animal Feed Ingredient like Oil Cake

- Wrongful Dependence on Artificial Insemination from Imported Breeds of Bulls for Improving the Cattle Stock since the 1940s without any Visible Success

- Negligence and Apathy in the Systematic, Identification Selection and Breeding of different local races of Cattle for Improvement.

\subsection{Case Study: Case Study on Biodiversity of Sundarban and Its Depletion}

Sundarbans is the World largest mangrove forest, $62 \%$ in Bangladesh and $38 \%$ in West Bengal. The area of Sundarbans in Bangladesh is 6017 sk.km. (70\% land and 30\% water). Sundarbans forest is situated on the Southwest coastal areas and it is the largest forest in Bangladesh having 6017 sq. miles of areas. The areas $99 \%$ covered by the districts of Sathkhira, Khulna and Bagerhat while other areas are in Patuakhali and Barguna districts. Rajmongal and Burishwar stand on the east and west side of Sundarbans respectively.

The Sundarbans Researve Forest (SRF) are situated at the southern part of Khulna, Bagerhat and Satkhira civil district lying in between latitude $21^{\circ} 27^{\prime} 30^{\prime \prime}$ and $22^{\circ} 30^{\prime} 00^{\prime \prime}$ North longitude $89^{\circ} 02^{\prime} 00^{\prime \prime}$ and $90^{\circ} 00^{\prime} 00^{\prime \prime}$ East (Map $1 \& 2$ ).

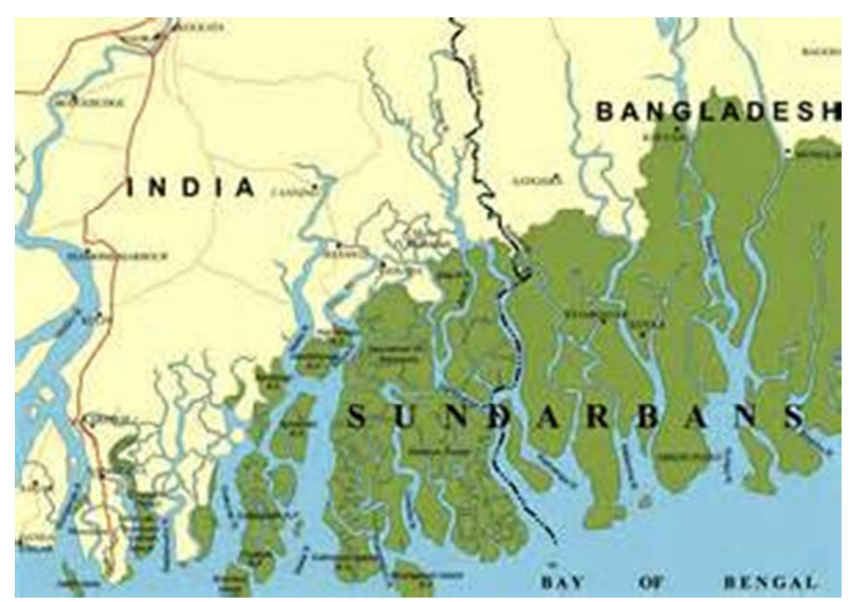

Map 1. Map of Sundarbans and surrounding area of Bangladesh.

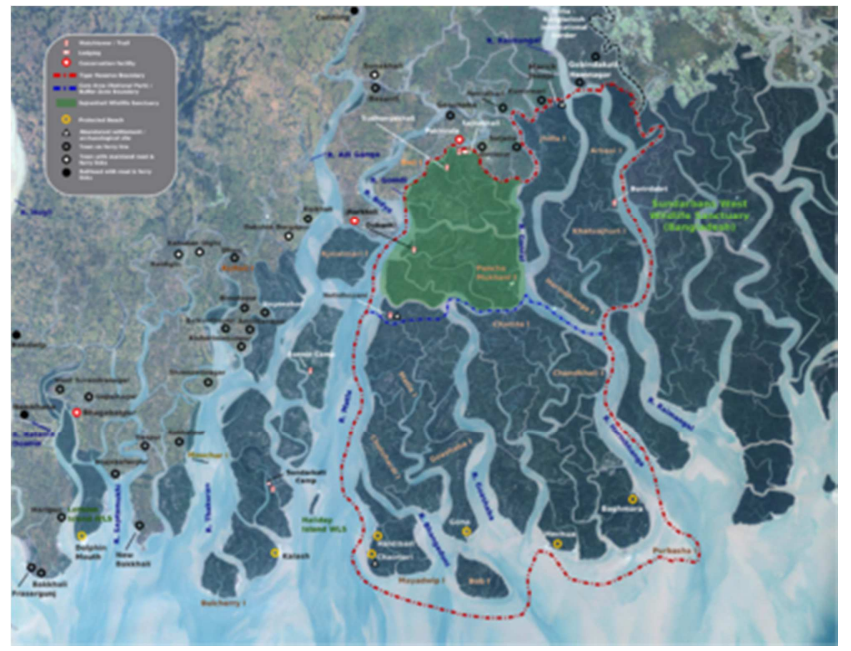

Map 2. Tiger reserve areas of Sundarban (Dark Green: Biosphere reserve).

About 450 large and small rivers in Sundarban, Baleswar and Pusur rivers bring fresh water from Padma to Sundarban. There are rivers and canals spread across this forest like a net with their innumerable branches. Nearly 450 large and small rivers occupy about 1 lakh 75 thousands 685 hectares or about $30(\%)$ of the Sundarbans. The Biggest River is the Pusur. Other rivers worth mention are Baleswar, Sibsa, Arpangasia, Bhola, Horinbhanga, Kalindi, Andharmanik, Raimangal, Kapotaksha, Koira, and Shela Bhadra etc. As one proceeds to the south, the rivers widen. Some rivers are so wide that one cannot see one bank form the other. Baleswar and Pusur rivers and their tributaries and disrbutaries are connected with the Ganges. As a result these rivers and their branches have flow of fresh water. The sibsa and other rivers in the western part have their source of fresh water only in the Ganges and the northern portion of the Sundarbans 
depends upon the rainwater. As a result, the fresh water flow in these rivers decreases during the dry season when there is a massive intrusion of saline water. Moreover, the condition of the rivers and canals in the Sundarbans is deteriorating shoals are forming and navigability is declining. River erosion is taking place at some places.

The rivers, canals, creeks etc. spread across of Sundarbans like a net with their innumerable branches. There are neatly 450 large and small rivers that occupy the water areas of the Sundarbans. The biggest river is the pasur. Other rivers worth-mentioning are the Baleswar, the Sibsa, the Arpangasia, the Bhola, the Horinbhanga, the Kalindi, the Andharmanik, the Raimangal, the Kapotaksha, the Koira, the Shela Bhadra etc. As they once proceed to the south, the rivers become widen.

There are about 102 Islands in the Sundarhans of which some 58 Islands are inhabited. A large number of these inhabitants are directly or indirectly involved in fishing, fry collection or fish marketing etc.

Floral and faunal diversity of Sundarban

Sundarban is a large unique mangrove ecosystem habitat in the world. This mangrove habitat is abundant of many rare and endemic species. Sundarban mangroves are habitats of many endangered animals viz., Batagur baska, Pelochelys bibroni, Chelonia mydas). World famous Royal Bengal Tiger (Panthera tigris), Spectacular Spotted Deer (Axis axis), Jungle Fowl (Gallus lafayetii) and Rhesus Monkey (Macaca mulata) are critically endangered.The forest has a unique biota comprising 334 species of plants, 49 species of mammals, as many as 400 species of fish, 315 species of birds and 53 species of reptiles [24, 25]. Besides numerous species of Phytoplankton, Fungi, Bacteria, Zooplankton, Benthic Invertebrates, Molluscs, Reptiles, Amphibia and Mammals are found in the Sunderbans. Species composition and community structure varies east to west, and along the hydrological and salinity gradients. The forest is particularly important as a barrier to tidal cyclones.

The mangroves of the Sundarban are unique prime species are sundari (Heritiera littoralis), from which the Sundarban takes its name. There are four types viz., low mangrove forests, tree mangrove forests, salt-water Heritiera forests and freshwater Heritiera forests. Ecoecaria agallocha, a dense understory of Goran (Ceriops decandra) and dense patches of Hantal palm (Phoenix palludosa) on drier soils. Dhundal (Xylocarpu granatum) and Passur (Xylocarpu mekongennnsis) and Bakul kankra (Bruguiera sexangule) sporadically found throughout the area [12].

Five species, viz., Javan Rhinoceros (Rhinoceros sondaicus) (CR), Wild Buffalo (Bubalus bubalis) (EN), Swamp Deer (Cervus duvauceli) (VU), Gaur (Bos frontalis) (VU) and probably Hog Deer (Axis porcinus) (LR) have become extinct [12].

A total 315 species of bird have been recorded by [4]. Stork-Billed kingfishers (Pelargopsis amauropterus), Whitebellied Sea-Eagle (Haliaeetus zeucogaster), Grey-Headed Fish Eagle (Zchthyophaga ichthyaetus), Pallas's Fish-Eagle (Haliaeetus zeucoryphus), Raptors (Leptoptillos dubius),
Herons (Ardeola grayii), Egrets (Bubulcus ibis), Storkas (Cochoa purpurea), Sandpipers (Actitis hypoleucos), whimbrel (Numenius phaeopus), Curlew (Numenius phaeopus), Woodpeckers (Micropternus brachyurus), Mynahs (Gracula religiosa), Minivets (Pricrocotus flammeus), babblers (Pomatorhinus horsfieldii) are found in dry season [4].

Reptile 53 and 8 amphibians species have been recorded from Sundarbans by [4]. Mugger (Crocodylus palustris) (Vulnarable) is now extinct. Estuarine crocodile (Crocodylus porosus) still now survives but its numbers have been greatly depleted [4].

Four species of marine turtle have been recorded from the Sunderbans by [12], Olive Ridley (Lepidochelys olivacea) (EN=Endangered), Green turtle (Chelonia mydas) (EN), Loggerhead (Caretta caretta) (EN), Hawksbill (Eretmochelys imbricate) (Critically Endangered) are found in Sundarban. King Cobra (Ophiophagus hannah) and Spectacled Cobra (Naja naja) three Vipers and six Seasnakes are recorded in Sundarban. Shrimps, Prawns and Lobsters are rich in water of canals and rivers [12].

\section{Impact of Climate Change on Sunderbans}

Sundarban wetlands, freshwater reaching the mangroves was considerably reduced from the late $19^{\text {th }}$ century due to diversion of freshwater in the upstream area. As a result, the salinity increased of the Sundarban. The sea level rise due to global warming and then the vulnerability to tropical cyclone storm surge flooding increase in the Sundarban areas [36].

\section{SIDR (Tidal Cyclone)}

Barguna, Pautuakhali, Jhalokati, Pirojpur, Bagerhat, Barisal, Bhola, Lakshmipur, Chandpur. Madaripur, Shariatpur, Munshigong, Narayanganj. Dhaka, Comilla, Bramanbaria, Narsingdi, Habigang. Kishoregonj, Maulvi Bazar, Sunamganj and Sylhet district of Bangladesh were affected by the tidal cyclone SIDR. In 2007 super cyclone SIDR, originating in the Bay, ravaged the entire south and southwestern coast with peaking winds over $220 \mathrm{~km}$ on November 15 . This coastline is homeless of nearly 12 million people. At least 5,000 people have been died caused by cyclone SIDR. The flora and fauna of the Sundarbans, became a major casualty of the devastating cyclone. The Forest Department is yet to make an assessment of the colossal losses of wildlife in the Sundarbans.

SIDR damaged $25 \%$ of the south eastern part of the Sundarbans. Out the damaged area 7\% (ca 30,000ha) damage was severe $18 \%$ (ca.77000ha) damage was partial. SIDR uprooted and broke severely damaged crown of still standing trees, foliage have been striped off from branches of trees in nearly one third of the Sundarbans mainly including the World heritage Sites, many forest stations, boats, jetties etc have been severely damaged, fresh water ponds have been contaminated by saline water, six out posts have been totally destroyed. Two tigers, 23 deer, I forest staff have been found dead because of tidal upsurge. Residential accommodation of nearly 1000 persons has been badly damaged or washed away. Sundarbans will require years to recover from the damage. Forest Department's official apprehension that the 
total damage of all kind might amount to US\$145 million while Governments official source supports suggest the damage to be US\$150 million Forest Departments strategies are to rebuild damaged outpost, revive the safe drinking fresh water, mark and estimate fallen trees and record them by species make fill scale estimation of damage, assist in natural regeneration and plant where necessary.

\section{AILA (Tidal Cyclone)}

At least 300 people have been died, 8,208 more missing, 1 million people homeless, 20 million people at risk of post disaster diseases due to Aila. The majority portion of the biosphere reserve was destroyed by the Aila. The gradual climatic change gave back a heavy return which not only had a great impact on the life of the dwellers in the mentioned region but also made them aware of the benefits of the mangrove forests [http://www.surfat10.com/climateicare]. Salinity and Sea Salinity Rise Threaten on Sundarban.

Many diseases, like 'Agamora' (top dying), affect different species of plants and trees, including the Sundari tree (Heritiera littoralis), in the Satkhira district due to the salinity intrusion in Range of the Sundarbans. Rising salinity in rivers, canals and other water bodies in the mangrove forest was also one of the reasons for the death of trees. Sundari (Heritiera littoralis), Passur (Xylocarpu mekongennnsis), Keora (Sonneratia apetala), Gewa (Excoecaria agallocha), Baen (Avcennia officinalis), Goran (Ceriops decandra), Hantal palm (Phoenix palludosa), Dhundal (Xylocarpu granatum), Bet (Calamus tenuis), Jhau (Tamarix galica) and Hogla (Typha elephantiana) affected by 'Agamora' (top dying) disease due to salinity intrusion in the sundarban area [14]. Many species of animals and birds have been facing extinction due to salinity on the soil and water in the sundarban area.

Endangered and Extinct Species of Sunderbans

Axis porcinus, Wild buffalo (Bubalus bubalis), Swamp Deer (Cervus duvauceli), Javan Rhinoceros (Rhinoceros sondaicus) and the Mugger Crocodile or Marsh Crocodile (Crocodylus palustris) have been extinct in the Sundarbans recorded by [14]. Royal Bengal Tiger (Panthera tigris) Estuarine Crocodile (Crocodylus prosus), River Terrapin (Batagur baska), Olive Ridley Turtle (Lepidochelys olivacea) (EN) Green turtle (Chelonia mydas) (EN), Gangetic Dolphin (Platanista gangetica), Hawks Bill Turtle (Eretnochelys imbricate) and King Crabs (Horse shoe) are endangered species of Sundarban [4]. Capped Langur (Semnopithecus pileatus), Smooth-Coated Otter (Lutrogale perspicillata), Oriental Small-Clawed Otter (Aonyx cinerea) and Great Indian Civet (Viverra zibetha) are threatened [14].

\section{Illegal Practice of Sundarban Biodiversity}

The total area of Sundarban in Bangladesh is calculated about 5800 sq.km including rivers and Canals. Wild species such as wild buffalo, Bengal Rhinoceros, Swamp deer have already become extinct from this forest. About two species of amphibians, fourteen species of reptiles, twenty five species of birds, five species of mammals have now become extinct from the Sundarban. Some natural phenomena and human interventions are the main causes in this regard. There are about 334 species of trees including vegetation, creepers, and harbs are available in the forest. Peoples are authorized with legal endorsement in the forest to catch fish, collect honey, Golpata and Gewa tree and there are frequent illegal trespassers among them who collect the natural resources indiscriminately.

There are many valuable trees in the Sundarban which should be preserved to save the ecosystem and biodiversity of Sundarban. But unfortunately the ecosystem and biodiversity of Sundarban is damaging day by day because of illegal activities trough the Sundarban. Sundarban is being a crime zone day by day and it is using as safe zone to the criminals. A few groups of terrorists are placed in Sundarban and they are doing crime in the surrounding area. Criminals loot the locals and hand over the valuable trees to the black market. Stealing is a common practice in Sundarban by which Sundarban is losing its valuable assets day by day. Anthropogenetic impacts like reclamation, human encroachment and influence plays a vital role to increase the depletion of biodiversity of Sundarban. High salinity, low water table and acidity problem, loss of soil fertility, coastal erosion and a steep fall in fishery resources, conversion of mangrove tracts for aquaculture and agriculture Extension of other non forestry land use into mangrove forest, uncontrolled collection of prawn seedling, pollution from both the landward and seaward sides are also the illegal practice in Sundarban. Hunting different kinds of valuable animal like tiger, deer, crocodile, birds, snakes etc is the most affective illegal practice in Sundarban which are seriously damaging the ecosystem of Sundarban.

Causes of Depletion in Biodiversity of Sunderbans

The sundarban bio-diversity is threatened by unabated poaching, increasing conversion of the forest land for agriculture, shrimp farming, hunting, illegal felling of trees, exotic plant plantation, unplanned and over extraction of resources and insufficient conservation effort.

Natural calamities like storms, cyclones and tornadoes pose a big threat to trees. More than a dozen of cyclones have hit the Sundarbans during the last decade. Some ecological changes like increase in salinity, diseases like "top dying" of the Sundari trees a serious threat to rich biodiversity of the Sundarbans.

Diversion of the natural courses of rivers, construction of embankments, dams and bridges in the upstream as well as decreased flow of freshwater in the rivers resulted in the increase in salinity level and over-silting in many places and caused subsequent changes in the mangrove ecosystem. In the Sundarbans, for bringing non-commercial cover areas under tree cover in different areas of Chandpai, Sarankhola and Khulna forest ranges, plantation of exotic species, like Acacia nilotica and Alibizia procera have taken place. Though at a limited scale, many other exotic species have been introduced in the Sundarbans mangrove ecosystems, particularly in areas around the forest offices. It is apprehended that these exotic species may pose a threat to the native variety of mangrove species.

Wild Buffalo, 2 species of Deer, Javan Rhinoceros extinct 
and presently 2 species of amphibians, 14 species of reptiles, 25 species of birds and 5 species of mammals are considered as endangered species reported by [25].

Causes of Depletion of Biodiversity of Sundarban

1) Anthropogenic activities

2) Causes of neo-tectonic movement of the Bengal Basin

3) Global Warming and Sea Level Raise

4) Huge silt Deposition of river and canal in the sundarban area

5) Salinity intrusion

6) Reduction in Periodicity and Quantity of Freshwater Reaching the Mangrove Environment due to Diversion of Freshwater in the Upstream Areas (especially due Farakka Barrage Constructed by India) and Change in Course of main rivers

7) Conversion of Mangrove Tracts for Aquaculture and Agriculture

8) Over wood extraction.

9) Illegal hunting of Tiger, Deer, Wild Boar, Marine Turtles and Horse Shoe Crab etc.

10) Illegal practices of prawn farming.

11) Illegal fishing and overfishing

12) Uncontrolled Prawn Seed Collecton

13) Pollution from usage of Excessive Pesticides, Chemicals for Agricultures, Industries, Exploitation of Mineral Gas and Oil etc.

14) Organizational and Infrastructure Deficiencies;

15) Lack of Public Awareness

16) Lack of trained manpower

Study on the search of appropriate cause of biodiversity depletion in Sunderban region has provided an insight which is in need of immediate implementation. Such as the conservation attempt by the government must be accentuated by the local people. This can be materialized by managing alternative employment opportunities of those whose livelihood rests on Sunderban and by developing sustainable management procedure which will replenish the loss of resources for the local livelihood sustenance.

Secondly, the most troublesome cause that has been identified by our study is climate change impact. Recent cyclone like SIDR, AILA has devastated the entire region by striking on the long trees and by depleting the wild animals, even the tiger has been found dead after the disaster. Hence, an intensive and immediate measure is to be taken so that a proper strategy can be put in place before any such calamity strikes soon.

Consequences of Mangrove deplation

The mangroves plantations are the breeding grounds for thousands of species which thrive in a combination of saline and freshwater reservoirs. Due to illegal cutting and grazing the mangroves are rapidly vanishing.

If current trends persist then entire biodiversity of the area would be lost, also leading to serious social and economic repercussions. Over 90 percent of the population of sunderbans are illiterate and lives well below the poverty line. If the sunderbans forest is exhausted not only that area would be vulnerable to cyclones, but also innumerable fishermen would loose their livelihood and their way of life hence it's vital for the ecosystem without which this fragile habitat would fall victim to extinction.

\subsection{Case Study: Causes of Biodiversity Depletion of Chalan Beel Area}

Chalan beel is the largest wetland, water body and natural water reserver in Bangladesh. It covers the area of eight upzilas of three districts, namely Natore, Sirajgonj and Pabna Singra, Boraigram and Gurudaspur of Natore, Taras, Raigonj and a part of Ullapara of Sirajgonj, Chatmohor and Vangura of Pabna districts come within the range of Chalanbeel. It is some 2000 square kilometers in its size, 51 kilometers in length (east-west) and 39 kilometers in its width (northsouth).

Once it stretched from Raninagor, Atrai of Naogan to Faridpur, Bera and Sador of Pabna, as well as Nandigram and Adamdighi of Bogra district. But now it has diminished in its size owing to siltation. The construction of highway has also had a negative impact on its size.

The topography of the land is low. The area is about 25 meters high from the sea levels. The area is under Agro Ecological Zone (AEZ) named High Ganges River Flood plain. There is an overall pattern of olive-brown silt loams and silty clay loams calcareous soils. Organic matter content in the soil is low. Soils are slightly alkaline in reaction. General fertility level is very high.

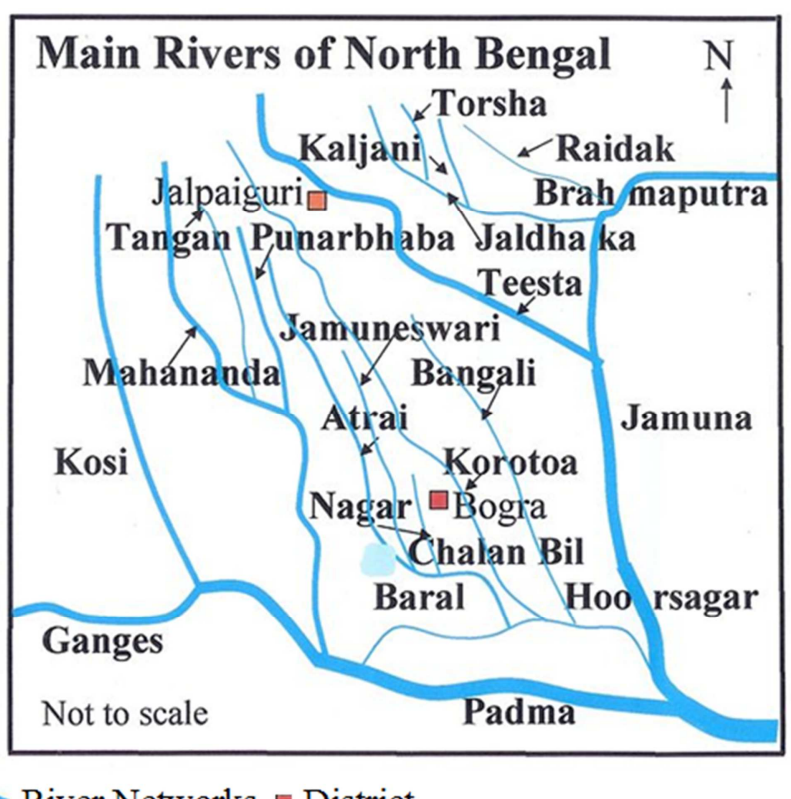

River Networks, $\square$ District

Map 3. Overview map showing Chalan Beel among the main rivers in North Bengal of Bangladesh.

\section{Climate and Temperature of Chalan beel Area}

The climate of this area is mainly warm and moist also. In terms of moisture chalanbeel resembles Rajshahi. The temperature of this region is on average from maximum $35^{\circ} \mathrm{C}$ to minimum $25^{\circ} \mathrm{C}$. In winter it is from $12^{\circ} \mathrm{C}$ to $15^{\circ} \mathrm{C}$. 
Sometimes it increases to $45^{\circ} \mathrm{C}$ in summer and decreases $14^{\circ} \mathrm{C}$.

In 1909: The original area of the chalan beel was above $1088 \mathrm{~km}^{2}$ [29].

Current area of beel is $375 \mathrm{~km}^{2}$. The study area is less populated than other parts of Bangladesh. About 1749484 people live here in 64 union councils, 7 municipalities, and 1878 villages. Average family size is 6 , literacy rate 40 and 37.36 male and female respectively. About $82 \%$ population is Muslim, 16\% Hindus and others 2\%.

Purba Maddhanagar, Piprul, Dangapara, Laror, Tajpur, Niala, Chalan, Majhagaon, Briasho, Chonmohan, Satail,
Khardaha, Darikushi, Kajipara, Gajna, Bara, Sonapatila, Ghugudaha, Kuralia, Chiral, Dikshi and Gurka are main depression of Chalan beel. The big-size depressions are mostly in Pabna district which are Gajna, Bara, Sonapatila, Ghugudaha, Chiral and Gurka. Gajna beel cover an area of $123 \mathrm{sq} \mathrm{km}$. Bara beel covers an area of $31 \mathrm{sq} \mathrm{km}$. Sonapatila beel in Pabna which an area of $35 \mathrm{sq} \mathrm{km} \mathrm{[29].}$

About 10,000 families live on fishing and this number increases to the number of 30,000 in the rainy season. A great number of families depend on farming, business and other occupation.

Road and Communication (Table 3)

Table 3. Constructions on Boral River in several times.

\begin{tabular}{lll}
\hline Locations & Construction Year & Construction Agency \\
\hline Charghat Sluis Gate, Rajshahi & 1985 & Water Development Board \\
Ramnagar Dam, Chatmahar & 1986 & Up-Zilla Parishad \\
Bodhar Dam, Chatmahar & 1987 & Up-Zilla Parishad \\
Natun Kheya Ghat, Chatmahar & 1988 & Up-Zilla Parishad \\
Dohopara Sluis Gate, Chatmahar & 1988 & Up-Zilla Parishad \\
\hline
\end{tabular}

As it is a lower wetland, the modern communication system has not developed even in this scientific age. Boats and carts are still the main mode of transport and communication. Though a number of upzilas and districts are linked with metalled and semi-metalled roads and streets, no particular improvement could be found in communication. Natore-Nagorbari highway, Bogra-Natore
Bogra-SirajgonjI highway and recently built Hatikumrul, Bonpara-Dhaka highway has contributed greatly to the development of the people of this area. Atrai, and Gour, Karatoa and Fulzhor, Boral, Barnoi, Tulsi, Chechua, Vadai, Chiknai, Bangonga and Khubjipur Telkupi are of the main rivers of this area. Different waterbodies under Chalan beel and their areas are presented in table 4.

Table 4. Different waterbodies under Chalan beel and their area.

\begin{tabular}{llll}
\hline Type of water body & Number & Dry season Area (ha) & Monsoon Area (ha) \\
\hline Rivers & 21 & 709 & 3300 \\
Beels & 93 & 2227 & 9164 \\
Floodplain & - & - & 22369 \\
Ponds & 12817 & 2293 & 2617 \\
Borrow pits & 214 & - & 50 \\
Total & - & 5229 & 37500 \\
\hline
\end{tabular}

(Sources: [29] and Upazila Fisheries Offices (2006).)Fishes of Chalan Beel

Chalan beel is the heaven of fish. The number of fishermen family in this area is 10000 in dry season and 30000 in the rainy season. The fish hunters freely collect their fish in the marshes and flooded land of the area.

Every year 12,255 metric tons of fish are caught only in the rainy season and thereby some 72 crores 2 lacs 55 thousand tk at tk. 60 per $\mathrm{kg}$ is earned every year. The amount of fishes can meet the demands of the local people and can be exported to other regions of the country as well. The availability of the agricultural and fishing land of Chalan beel and the surrounding is decreasing day by day due to increased demands of settlements.

A total of 81 fish species were recorded from Chalan Beel including 72 indigenous fish species and nine exotic species [26]. Small freshwater prawns, crabs and some other fisheries items were very common in Chalan Beel. The available fish were recorded in the Chalan Beel Area. The available fish were recorded in the Chalan Beel Area (Table 5).

Majority drying were done by spreading raw fishes on bamboo rack without any protection measure from insects or dust. Among birds are as follows in table 6 [27].

Migratory Birds of the Chalan beel Area

Titihas (Anas platyrhynchos), Pamtamukhy (Anas plapeata), Lenja has (Anas acuta), Chiti has (Anas platyrhynchos) etc.

List of Plant Diversity in the Study Area

Paddy is the only crop because the depth of water in the rainy season is $6 / 7$ meter.

Though the region is farmed only once, 51 thousand 30 metric ton is produced in 1 lac 20 thousand hector lands, 50\% of the total products are transport to other regions of the country. Once Amon, Aus and Boro were the main type of paddy which was produced in this area but at the advent of IRRI (International Rice Research Institute) the farmers are getting benefited. In the relatively highland of this region some other crops are also produced. These include Wheat (Triticum aestivum), Onion (Allium cepa), Garlic (Allium stivum), Black gram (Vigna mungo) and vegetables. Among the fruits are as follows in table 7. 
Table 5. Fish fauna in Chalan beel.

\begin{tabular}{|c|c|c|c|}
\hline Local Name & Scientific Name & Local Name & Scientific Name \\
\hline Mola & Amblypharyngodon mola & Bele & Awaous gramтеротиs \\
\hline Bailla & Awaous guamensis & Katol & Catla catla \\
\hline Baghair & Bagarius bagarius & Guratengra & Chandramara chandramara \\
\hline Bata & Bangana. Ariza & Tengra & Batasio tengana \\
\hline Tengra & Batasio batasio & Lombachanda & Chanda nama \\
\hline Gozar & Channa marulius & Hatchetfish & Chela cachius \\
\hline Gachua & C. orientalis & Chital & Chitala chitala \\
\hline Taki & C. punctata & Mrigal & Cirrhinus cirrhosus \\
\hline Shol & C. striata & Koi & Clarias batrachus \\
\hline Kachki & Corica soborna & Muri bacha & Eutropiichthys muriu \\
\hline Olive danio & Danio dangila & Rivercatfish & E. vacha \\
\hline Banspata & Devario devario & Gang tengra & Gagata cenia \\
\hline Bhut bele & Eleotris fusca & Catfish & G. youssoufi \\
\hline Darkina & Esomus danricus & Ghor poa & Garra annandalei \\
\hline Bele & Glossogobius giuris & Angra labeo & Labeo angra \\
\hline Kani tengra & Glyptothorax cavia & Bata & L. bata \\
\hline Chapila & Gonialosa manmina & Ghonia & L. boggut \\
\hline Shingi & Heteropneustes fossilis & Kalibaus & L. calbasu \\
\hline Ghora mach & Labeo dyocheilus & Baitka & L. pangusia \\
\hline Rui & L. rohita & Madhu pabda & Ompok pabda \\
\hline Chep chela & Laubuca laubuca & Kani pabda & O. bimaculatus \\
\hline Gutum & Lepidocephalichthys annandalei & Chital & Notopterus notopterus \\
\hline Puiya & L. berdmorei & Batasi & N. atherinoides \\
\hline Tara baim & Macrognathus aculeatus & Nodoi & Nandus nandus \\
\hline Baim & Mastacembelus armatus & Gangatic mystus & Mystus cavasius \\
\hline Along & Megarasbora elanga & Kuchia & Monopterus cuchia \\
\hline Pangas & Pangasius pangasius & Bhol & Raiamas bola \\
\hline Ranga chanda & Parambassis ranga & Darkina & Rasbora rasbora \\
\hline Snake eel & Pisodonophis cancrivorus & Khorsula & Rhinomugil corsula \\
\hline Gang magur & Plotosus canius & Tit punti & Puntius ticto \\
\hline Punti & Puntius chola & Bhadi punti & P. sophore \\
\hline Kanchan punti & P. conchonius & Shorpunti & P. sarana \\
\hline Rita & Rita rita & Chela & Salmophasia acinaces \\
\hline Chela & Salmophasia phulo & Chela & S. bacaila \\
\hline Savon khorka & Schistura Savona & Phasa & Setipinna phasa \\
\hline Ayre & Sperata aor & Tepa & Tetraodon cutcutia \\
\hline Potka & Tetraodon fluviatilis & Khailsha & Trichogaster fasciata \\
\hline Lal kholisha & Trichogaster lalius & Boal & Wallago attu \\
\hline Kakila & Xenentodon cancila & & \\
\hline
\end{tabular}

Table 6. Native Birds of Chalan beel.

\begin{tabular}{llll}
\hline Local Name & Scientific Name & Local Name & Scientific Name \\
\hline Balihas & Nettapus coromandelianus & Chokha Chokhi & Tadorna ferruginea \\
Manikjor & Ciconia episcopus & King Fisher & Alcedo atthis \\
Tiya & Psittacuua krameri & Kokil & Eudynamys scolopacea \\
Bokkodal & Platalea leucorodia & Tilagugu & Streptopelia chinensis \\
Gang Salic & Acridotheres ginginianus & Fishing Eagole & Haliaetus leucoryphus \\
Babui & Ploceus philippimus & Kana Bok & Ardeola grayii \\
Pankori & Phalacrocorax niger & Crane & Grus antigone \\
Dahuk & Amaurornis phoenicurus & Kora & Gallicrex cinerea \\
Sada Bok & Egretta garzetta & Choroi & Passer domesticus, etc. \\
\hline
\end{tabular}


Table 7. Available fruit gardens in Chalan beel areas.

\begin{tabular}{llll}
\hline Local Name & Scientific Name & Local Name & Scientific Name \\
\hline Mango & Mangifera indica & Jujube & Ziziphus zizyphus \\
Elephant apple & Dillenia indica & Wood apple & Aegle marmelos \\
Golden apple & Spondias cytherea, & Black berry & Rubus fruticosus \\
Amloky & Phyllanthus emblica & Dalim, & Punica granatum \\
Jamrul & Syzygium samarangense & Papaya & Carica papaya \\
Jackfruits & Artocarpus heterophyllus & Lichi & Litchi chiOnensis \\
Cucumbers & Cucumis sativus & Banana & Musa spp. \\
Coconut & Cocos nucifera & Makhna & Euryale ferox salis \\
Guava & Psidium guajava & Saluk & Nymphaea capensis \\
Sada Sapla & Nymphaea nouchalli & Paddo & Nelumbo nucifera \\
\hline
\end{tabular}

At present in different regions of Raigonj, some parts of Boriagram, and west part of Gurudaspur a huge amount of Garlic (Allium stivum), are being grown. Lichi (Litchi chinensis), is also being farmed in Nazipur of Gurudaspur nowadays.

Sustainability of agriculture is now a major global concern. In the study area the Sustainability of Chalan beel and the its surrounding is serious concern in the fact of lac of proper designing and planning of land use as a result, declining yield of agricultural production, fishing for increasing population.

The availability of the agricultural and fishing land of Chalan beel and the surrounding is decreasing day by day due to increased demands of settlements, roads and other non-agricultural uses. The crop yield has to be increased by using scientific land use planning, suitable crops selection, cropping patterns, used balanced fertilizers, pesticides, and other essential management practices. With the introduction of modern production systems, farmers disregard the traditional cropping practices such as mixed cropping, crop rotation and intercropping.

Depletion of Biodiversity in Chalan beel

As is the case with other parts of the country, the dam of Farakka is inevitably reducing the inflow of water in Chalan beel. As a result the diverse animal life in Chalan beel is heel is being obstructed in their movement.

Construction of railroads and a number of highways has greatly barred the free movement of the fishes and other water animal. The reproduction process of certain fishes and water animal are being hindered due to the railroads and highways. As a result some of the species of fish like Nodoi (Nandus nandus), Sarpoti (Puntius sarana), Bacha (Eutropiichthys muriu), Bata (Bangana ariza), Pangas (Pangasius pangasius) and Pabda (Ompok pabda) are becoming extinct. Even the water animals like Ud Biral (Lutra lutra), Mesobagh (Felis viverrina) have also become non-existent.

Closure of water movement use to Farakka and its resultant negative effects on the fertility compels the farmer of this area to use chemical fertilizers on their lands to increase the production. But though the practice of fertilizing leads to a greater production of crops, it ultimately affects the biodiversity negatively. Life of the fishes and other animal's dependent on the water of this region becomes a victim to the large amount of pesticides used by the farmers in this area.

Land Degradation of Chalan beel (Map 4 \& 5)

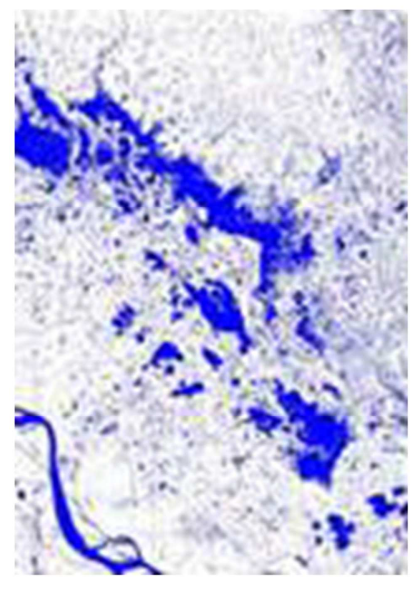

Wetland, 1989

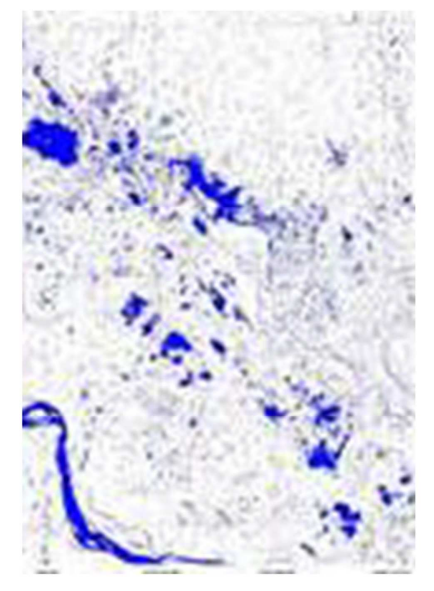

Wetland, 2001
Map 4. Chalan beel Wetland Decreasing day by day in every year.

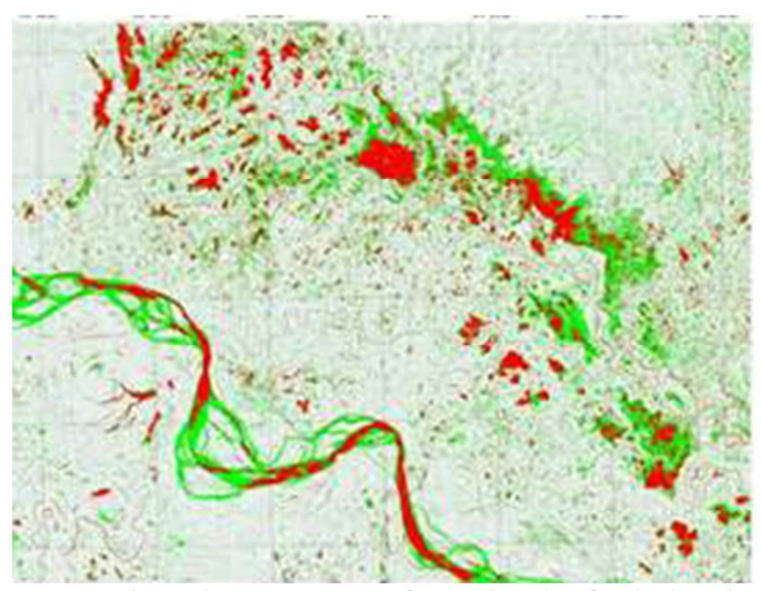

Map 5. Changing Pattern of Wetland of Chalan beel : Unchanged Wetland $\mathbb{Q}$ : Changed Wetland

Map 5. Changing Pattern of Wetland of Chalan beel.

Poverty and population growth, absence of a proper land use policy, over-exploitation of natural resources are major causes for land degradation of Chalan beel area. Soil degradation in the Chalan beel area results from unplanned land management. The extent of land degradation varies according to region, season, and year due to the diverse nature of the driving forces and causes [28, 29]. Land degradation in the Chalan beel is occurring mainly due to 
rapid changes in demography, traditional shifting cultivation practices, construction of roads and high ways and other physical infrastructure. Land degradation in the Chalan beel is caused mainly due to over exploitation of biomass from agricultural lands, and cultivation of HYV (High Yield Varity) rice.

Chalan beel was a riched very potential source of water resources. There was large green land in Chalan beel for which huge number of wild buffalo came here from Japaiguri of India. But for the misuse of that land the green field of Chalan beel is no more and the primary shape of the historical Chalan beel also got a dramatically change. Initially the Chalan beel was extended about eight hundred square kilometers [30] but today the major part of that area is reduced which are not possible to identify as the part of Chalan beel because of establishing village, constructing roads and high ways etc. [29]. In 1914 the Chalan beel is divided into two by the construction of Dhaka-Rajshahi Railway and finally the Sirajganj-Bonpara high way stopped its water flow. At once different kinds of dangerous animal like Mesobagh (Felis viverrina), Wild buffalo (Bubalus bubalis), Crocodile (Crocodylus prosus), Snake (Naja naja), Elephant (Elephas maximus) etc. were found openly in the area of Chalan beel but for the indiscriminate aggression to that area those animals are not found even in search. Chalan beel contributes the rich biodiversity of Bangladesh which is a valuable heritage of our present and future generations. Its value goes beyond the local context; it has a global significance. Over the last hundreds years, the country has lost about 10 percent of its biodiversity. Population pressure, habitat loss, pollution, and poaching are putting tremendous pressures on the existing biodiversity. But unfortunately, unplanned social development and illegal capturing of the water resources Chalan beel can not contribute globally even to our local biodiversity. If the current trend continues, many of the species will be endangered or be even extinct. In case of 'Chalan beel" these percentage of lost is near about $3 \%$. The condition of wetlands is even worse than that of forests. Most of the wetlands are being converted into agriculture land and degraded due to development activities. Chalan beel was a great source of fisheries but for collecting fish from Chalan beel indiscriminately damaging this source of fisheries day by day.

Negative Impact On Chalan Beel Ecosystem

Negative Impact of Fertilizer and Pesticide Uses (Table 8 \& 9)

Chemical fertilizer, pesticides, insecticides, herbicides, fungicides and rodenticides are commonly used in Bangladesh. The trends of irrigated land and use of chemical fertilizers and pesticides from 1991 to 1995 in Bangladesh are presented in fig-2. In 1991, the use of nitrogenous fertilizer along accounted for about $67 \%$ of total fertilizer use, which rose to $88 \%$ in 1995 . Per hectare use of urea for HYVs rice cultivation in the study area. It is found that more than $90 \%$ of the farmers use 298 to $334 \mathrm{~kg}$ of urea per hectare, which is much below the average use of urea for HYVs rice cultivation at national level (457 kg per hectare) [29].
Table 8. Consumption of Fertilizer in Singra Beel from 1985 to 2005 (per hectare in quintal).

\begin{tabular}{lllllll}
\hline \multirow{2}{*}{ Years } & \multicolumn{2}{l}{ Compost } & \multicolumn{2}{l}{ Chemical } & \multicolumn{2}{l}{ Grand total } \\
\cline { 2 - 7 } & Total & \% of total & Total & \% of total & Total & Percent (\%) \\
\hline 1985 & 14.28 & $65.56 \%$ & 7.5 & $34.44 \%$ & 21.78 & $100 \%$ \\
1995 & 6.31 & $17.75 \%$ & 29.23 & $82.25 \%$ & 35.54 & $100 \%$ \\
2005 & 2.59 & $3.09 \%$ & 81.2 & $96.91 \%$ & 83.79 & $100 \%$ \\
\hline
\end{tabular}

A part of land of Singra Upazila is being used for settlements and non-agricultural purpose, so landuse of Upazila center is not as in the rural areas. The main reason is enhanced of population. Agricultural activities have been developed in wetland area. Therefore, the landuse for agriculture has been developed in rural area and nonagricultural landuse has been developed in Upazila center. The population is increasing but not agricultural land. So the farmers are using chemical fertilizers to meet the demand of food for excess population and to take economic benefit from the land. The peasants are using chemical fertilizers and insecticides to increase production. Excess use of chemical fertilizer declines soil fertility.

The data of chemical fertilizer use in Singra Upazila is as below (Table 6) [28].

Table 9. Net Fertilized of Cultivated Area (hectare) in Singra Upazila (Sub District).

\begin{tabular}{llll}
\hline \multirow{2}{*}{ Net cultivable land } & \multicolumn{2}{l}{ Net fertilized area } \\
\cline { 3 - 4 } & & Total & $\mathbf{( \% )}$ \\
\hline 1985 & 113,312 & 37959.5 & 33.5 \\
1995 & 115,807 & 75981 & 65.61 \\
2005 & 120,168 & 110518 & 91.9696 \\
\hline
\end{tabular}

Main data source: Upazila Agricultural Office, Singra Upazila, Natore and Field Survey' 2005.

There has been no significant increase of total chemical fertilizer use at national level. But, significant increase in pesticide use has been observed which has serious implications to land and ecosystem. Application of pesticides in the study area still remains much below the national average $(0.35 \mathrm{~kg}$ per hectare). The local people of the study area claimed that fallow and grazing lands were turned into the lands of rice monoculture and thereby adversely affect the production of green cattle feed. In addition, they also mentioned that, the domestic animals eating pesticides affected grasses also suffer from health problems.

With the increased production of paddy there would be concomitant increase in paddy straw. But the palatability and digestibility of the straw has declined due to excessive use of chemical pesticides. The deep-water aman cultivation was a valuable source of supply of fresh cattle fodder. Moreover, farmers spraying pesticides suffer from heart and skin diseases because of ignorance.

Extensive monopoly of HYVs rice cultivation is removing other crops needed for nutritional welfare of the people. Such monoculture is depleting some specific soil nutrients very rapidly. Deficiency of different micro and macro elements is prevalent in the farming soils. With such complicated adversities, grain yield may be reduced. About $28 \%$ of the farmers blamed on the HYVs rice monoculure for the loss of 
soil fertility of the area. [29] in their study claimed that up to $40 \%$ of the fertilizers used are leached to low-lying areas where weeds proliferate and an unknown amount of pesticides end up in the irrigation and drainage system. It is also encourages a proliferation of weeds and algae growth which depletes the oxygen content of the water. They also claimed that, in the water of Chalan Beel, the contention of oxygen is only $3 \mathrm{mg} / \mathrm{Lin}$ the dry season and this is not enough to sustain aquatic life, which needs a minimum of $5 \mathrm{mg} / \mathrm{L}$. This may promote the formation of poisonous nitrates in the water. These conditions are responsible for the reduction in the fish population. There are frequent complaints from the Department of Fisheries about the agrochemical toxicity to the fishes. The high level of pesticides leached to the water sources has also been blamed for causing regular outbreaks of epidemic diseases in fishes and is said to have decimated the fish population in certain areas $[30,31]$. There is however, no detailed and specific study on the effects of pesticides on fisheries or on wildlife.

Ecological Characteristics of Chalan Beel

Water temperature $\left(11.5-40^{\circ} \mathrm{C}\right)$, air temperature $\left(8-40^{\circ} \mathrm{C}\right)$, water transparency $(18-55 \mathrm{~cm}), \mathrm{pH}(7.2-8.5)$, dissolved oxygen concentration (5.1-9.6ppm), free carbon dioxide (1.3-12.3ppm), carbonate alkalinity $(8.3-15 \mathrm{ppm})$ and bicarbonate alkalinity $(82-117 \mathrm{ppm})$ of chalan beel were recorded by [29]. Rivers, floodplains, beels and ponds constitute distinct habitat types in the Chalan beel. During inundation, however, floodplains also become open-access resources for fishing. When most of the beels and floodplains dry up, several large rivers retain deeper pools. Most owners drain their ponds (kuas) late in the dry season in order to harvest the remaining fish. No aquaculture in the rivers, beels and floodplain, although pond owners culture carps over the 6 to 9 month period when the grow-out conditions are optimal [29].

Illegal fishing were very common feature in Chalan Beel. Fishermen were harvesting fish without considering the natural broods tock or fry. Fishing nets were used in small meshed, capable of catching almost all types of fishes. During dry season, fishermen harvest fish from the beel by complete dewatering.

Impact of Irrigation on Chalan Beel Area (Figure 1 and Table 10)

The tremendous increase is made in the installation of shallow tube wells and Deep Tube wells for ground water in the Chalan Beel area during the last 30 years. In these areas the cropping pattern is mostly transplanted HYVs Boro/ Aus followed by the rain-fed transplanted Aman. As a result the land remains inundated in most of the seasons (about 6 to 8 months), which keeps adverse effects on soils because of continued oxygen deprivation in the sub-soils.

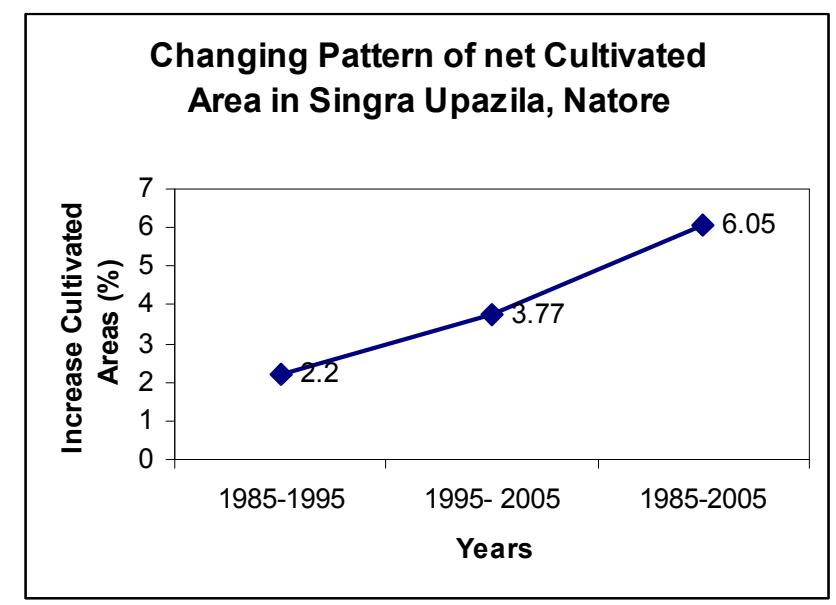

Figure 1. Changing Pattern of net Cultivated Area in Singra Upazila from 1985 to 2005 .

Main data Source: Agricultural Census, 1997, Upazila Agricultural Office, Singra Upazila, Natore and Field Survey' 2005.

Above figure 1 shows that the land use for cultivation in Singra has been increased to $2.2 \%$ in 1995 . The cultivable land use has been increased to $3.77 \%$ from 1995 to 2005 and it has been increased to $6.05 \%$ from 1985 to 2005 (Agricultural Census, 1996 and Field survey, 2005). So the land use for agriculture is increasing for increase of population. So the density of crops is also increasing.

Table 10. Land Use for Different Crops in Different Years (in hector).

\begin{tabular}{|c|c|c|c|c|c|c|c|c|}
\hline Crops & 2005-06 & $04-05$ & 03-04 & $02-03$ & 01-02 & $00-01$ & 99-00 & 98-99 \\
\hline Ropa Aman & 32300 & 32300 & 33100 & - & 32150 & 31000 & 30150 & 29500 \\
\hline Aus & 3300 & 4150 & 3160 & 2860 & 3600 & 2860 & 2170 & 1934 \\
\hline Bona Aman & 10100 & 10400 & 11150 & 9150 & 11000 & 9150 & 10830 & 10950 \\
\hline Mastered & 1900 & 2000 & 1650 & 1800 & 2300 & 0 & - & 1550 \\
\hline Wheat & 2250 & 2300 & 1895 & 1610 & 2000 & 0 & - & 1670 \\
\hline Boro & 31500 & 32100 & 32000 & 32100 & 32050 & 31310 & 30930 & 30660 \\
\hline
\end{tabular}

Singra Upazila Agricultural Office, Natore.

One cropland has been turned into two crops land, two crops land has been turned into three. The above table 10 shows that the maximum land is using for paddy cultivation. The excess cultivation makes land degradation. One crop is sustainable in Chalan beel area. It is not sustainable to cultivate many crops in Chalan beel area. During the rainy season there remains water in the beel area. When the beel area is remaining under floodwater then the silt and sand deposition occurs. Even floodwater causes damages to the crops. These types of land use-changing causes land degradation.

\section{Impacts of Different Factors on Chalan Beel Fisheries}

Siltation, construction of flood control embankments and roads, uncontrolled use of pesticides, insecticides and chemical fertilizers, excessive removal of surface water and 
extraction of groundwater for irrigation, diversion of water courses etc are main causes for degradation. These factors, which also contribute to already significant reductions of Chalan beel area.

Recommendations for Chalan beel Conservation

Modifying Existing Infrastructure on Chalan Beel

Bridges, culverts, sluice gates, flood control embankments, etc., has disrupted the spawning, breeding and feeding migration of fish and other aquatic animals due to unplanned development in the beel area.

Rational use of Chemical Fertilizers, Pesticides and implement of Integrated pest management (IPM) program.

a) Maintenance of Minimum Water Depth in the beel

b) Regulation of Selective Fish Gears, Mesh Sizes, and Fishing Dewatering

c) Establishment of Natural Beel Nurseries and Fish Sanctuaries

d) Strict Application of Existing Biodiversity Rules and Regulations

e) Establishment of Community-based Organizations (CBO)

f) Awareness Building

g) Construction of Eco-friendly Raver Dam

h) Construction Water Reserver

i) Training Programme for Stakeholder

j) Cannel and Water Bodies Link to each others

k) Established Permanent Fish Sanctuary Developed

1) Established Integrated Pest Management System

m) Proper Management of Industrial Effluent of Chalan Beel Area

n) Regulation of Selected Fish Gears, Mesh Sizes and Fishing Dewatering and Sanctuary

o) Maintenance Gene Tank

p) Established Community Based Organization (CBO)

q) Formation of Paying Ecosystem Service (PES)

r) Reconstruction of Ecosystem

i. Charghat Sludge Gate

ii. Atgori Sludge Gate

iii. Mini bridge and Culvert Reconstruction

iv. Water Bodies Reconstruction

v. Reconstruction of Existing 23000 Ponds

vi. Reconstruction of Boral River and to Link Every Water Bodies of Chalan beel

This section does not attempt to provide an extensive analysis of complex balance of environment and the interaction between the population growth and the use of land resource. Part of the reason is the difficulty in covering such a wide topic and dimension of the problems, as well as the inadequacy and range of data available that can facilitate critical analysis. However, it is found that the intensification of land use and it's associated externalities and spillover have produce environmental problems to a certain level in the area under study. The major types of environmental problems are as follows:

a. Degradation of Soil Quality Due to the Inundation of Land in most of the Seasons Round the year;

b. Decline of Soil Quality due to Increasing Incidence of
Unscientific HYVs rice Monoculture and Unbalanced use of Chemical Fertilizer;

c. Increased Pesticide use Particularly of Insecticides with Adverse Environmental Consequences;

d. Increased Health Problems due to Unbalance Use of Pesticides;

e. Substantial Reduction in the Supply of Cattle Fodder due to Over Harvesting;

f. Substantial Reductions in the Stock of Island Fish due to Use of Pesticides;

g. Increased Deforestation Due to Extension of Crop Production and Human Interventions;

The environmental impacts of land use in Chalan beel area may not be considered serious enough in the present context. Balanced and timely application of chemical fertilizers and pesticides will be helpful to improve the environmental quality at this stage. Application of strict regulative measures and creation of farmer's awareness should be considered as top priority in this respect. Integrated pest management and use of traditional knowledge (TKs) which are considered environmentally suitable may also reduce the use of chemical pesticides. To minimize soil nutrient depletion, monoculture of rice needs to be discouraged.

All the above measures may be effective for the present context of the area concerned. But the situation is not easy in the national concept. Bangladesh will have to ensure the supply of food for an additional 40-50 million people during the next twenty years. To meet the increased demand, it is essential that food grain output will have to expand 90 to $100 \%$ during the period. In order to meet the challenge the country may face serious environmental hazards in near future. The present knowledge about the process of land degradation because of unplanned efforts of production maximization is inadequate. The potentiality of preventing further degradation in future is also uncertain as the country suffers from lack of innovative technology friendly to environment.

Consequences of Chalan Beel Ecosystem

Chalan beel ecosystem comprise the increasing biotic and abiotic pressures.

Biotic

Uncontrolled siltation, infestation, waste water, industrial effluents, etc. resulting in increasing of aquatic weeds. Habitat destruction leading to loss of fish and decrease in number of animals in the beel area.

Abiotic

Anthropogenic pressures, uncontrolled dredging, hydrological intervention, pollution, chemical fertilizers are directly effect on habitat, biodiversity and aquifer in beel and there surrounding area.

\subsection{Case Study: Effects of Exotic Plantation and Its Implication on Biological Diversity: A Case Study on Modhupur Forest}

\section{About Modhupur Forest (Map 6)}

Among the different types of forests that exist the Modhupur Deciduous Forests (Dhaka, Tangail and Mymensingh) in Bangladesh stands out for its uniqueness. It 
is valuable in ecological aspects of natural forest. This tract is a large upland area in the central part of Bangladesh. This part is known as Modhupur Garh. It is a terrace from 1 to 10 metres above the adjacent floodplains areas. The total area of this forest is 4,244 sq km. The soils of the forest have developed largely on Modhupur clays. Which are nutrient poor and somewhat acidic and red or brown in colour. Average temperatures vary from 28 to $32^{\circ} \mathrm{C}$ in summer, falling to $20^{\circ} \mathrm{C}$ in winter, with extreme lows of $10^{\circ} \mathrm{C}$. Rainfall ranges between $1,000 \mathrm{~mm}$ and $1,500 \mathrm{~mm}$ annually. This tract is well known for jackfruit gardens. Kaliakair and Savar are also known for their production of mango, Bengal Olive, Pomelo and Star Apple, Pineapples are available in Modhupur.

Exotic Plantation in Modhupur Forest and Its Effects on Biological Diversity
Exotic species are harmful to native biodiversity such as, competitors, predators, parasites, and spreading disease. Consequently, the greatest threats to biodiversity. The Department of Forest is apparently depleting the Modhupur Sal Forest through implementation of different donor-funded aforestation projects, which mainly plant exotic trees of commercial value. The majority of the donor-funded projects in the past or the projects the government and development partners plan to implement shortly are about planting alien species of wood trees or constructing infrastructures inside the national park area of the forest. They are actually encouraged the officials to strip off natural trees and plant alien species including acacia, eucalyptus, goran, gamari and rubber. The indigenous Garos people were unwilling to take part, the department encouraged the Bangla-speaking people to resettle in the forestland.

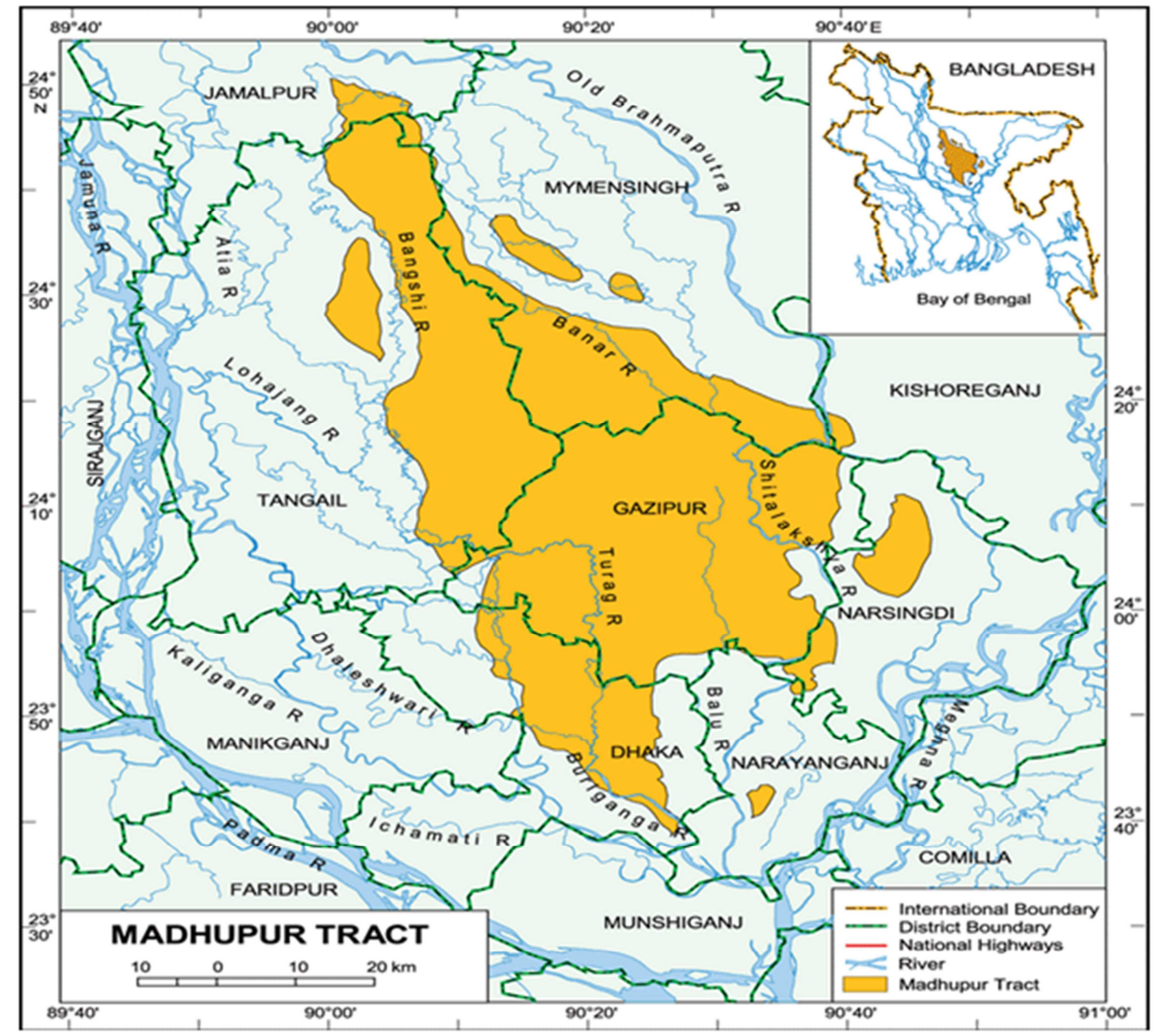

\section{Madhupur Tract}

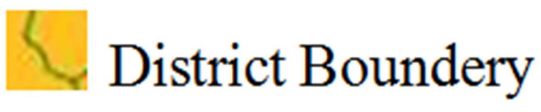

\section{River}

Map 6. Map of Modhupur Forest Area.

Natural Forest vs Anthropogenic Activities (Map 7)

Sal (Shorea robusta) was the dominant species of this track. About $600 \mathrm{sq} \mathrm{km}$ of forest remains and new woodlands planted with exotic species such as Akashi (Acacia auriculiformis) and eucalyptus (Eucalyptus camaldulensis) have transformed the ecosystem in many areas due to illegal forestation. [3] analysed a series of satellite images taken in between 1963 to 2003 and detected how the government officials cleared the forest and let others do it. They mentions in the summary that remote sensing techniques have shown quality degradation of the forest, signs of areas cleared for air force firing range and social forestry, conversion of forestland into rubber plantation, evidence of engulfing forests with settlement expansion, and indications of the 
influence of infrastructure. This study reveals that more than 85 percent of the Modhupur forest has been cleared in last 40 years. Whatever remains, in most of the areas the age of sal forest is not more than 10 to 15 years. Map 8 a comparison Forest Map Distribution in Madhupur tract Area

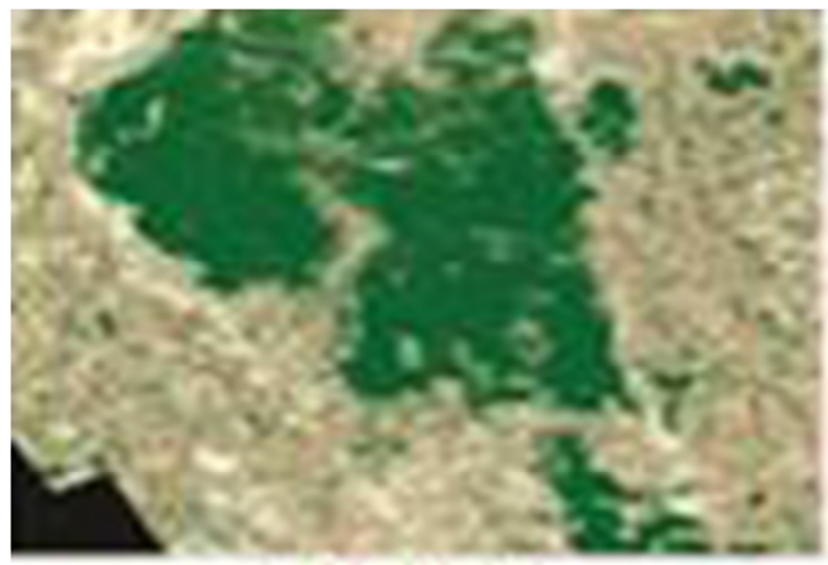

1962 (Corona)

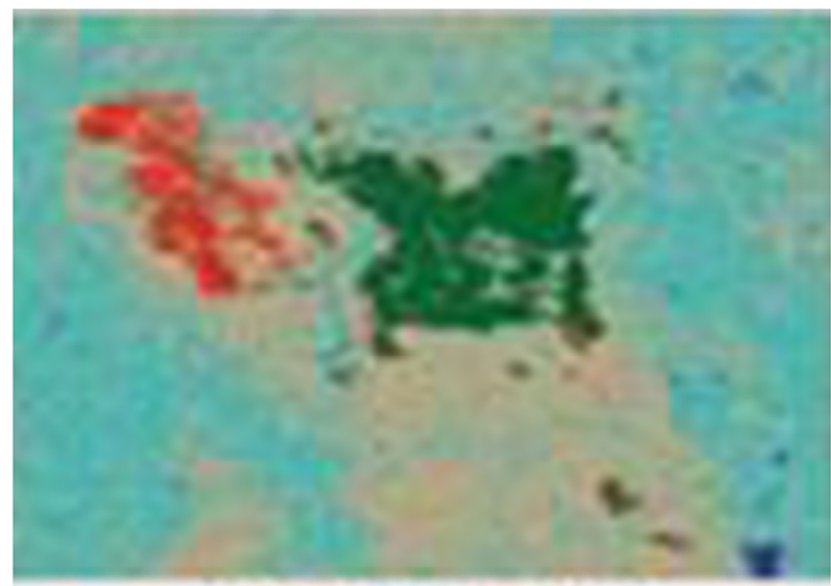

1991 (Landsat TM)

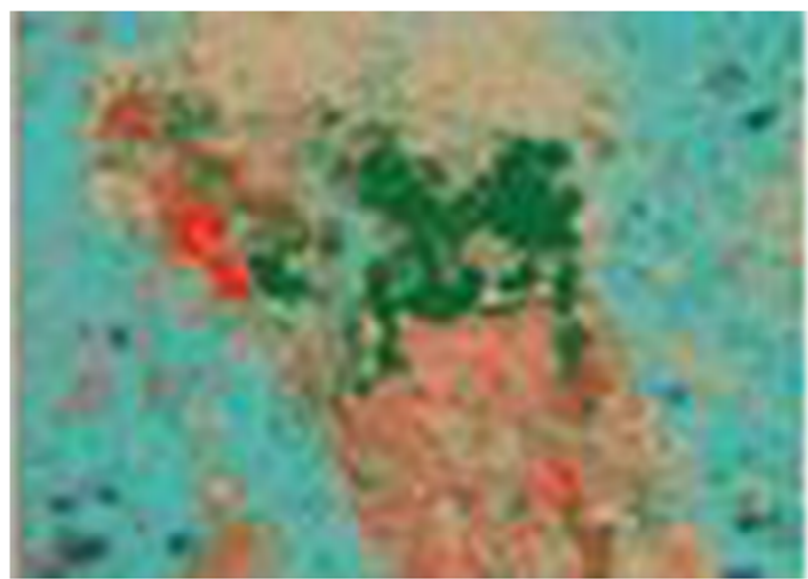

2002 (ASTER)

Flood Plain

Rubber/Exotic tree species

Forest Area (Closed, Open) of satellite images of 1962 and 2003 clearly shows 85 percent greenery of Modhupur has disappeared in last 40 years. Now noise of vehicles and bombings and shootings of the armed forces overwhelm the chirping of birds.

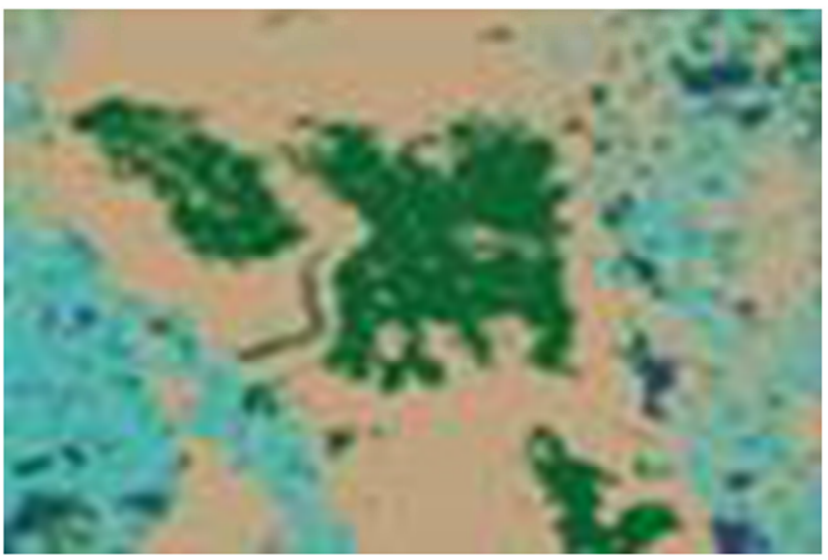

1977 (Landsat MSS)

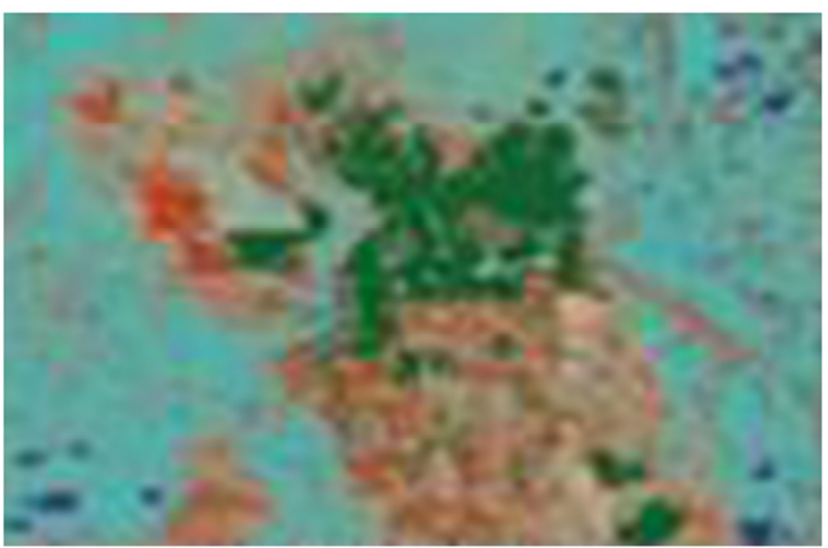

1997 (Landsat TM)

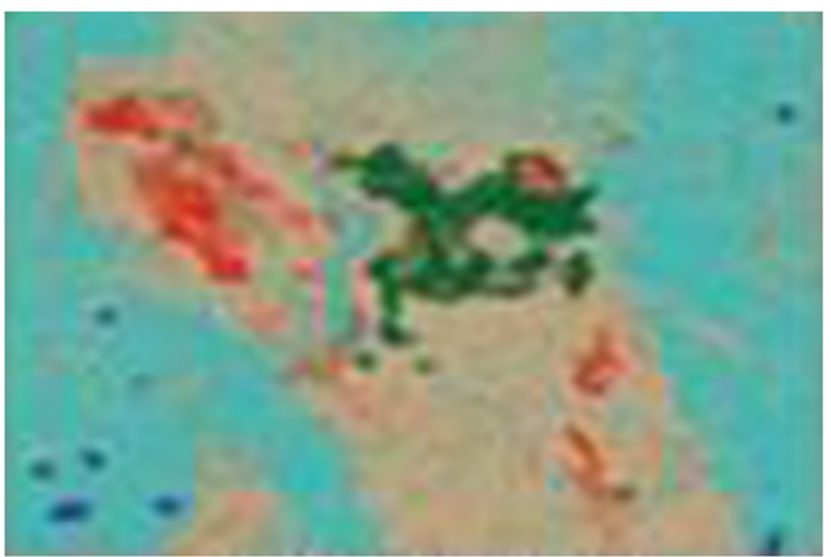

2003 (Landsat TM)

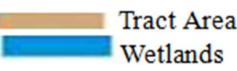

Map 7. Forest areas are Decrising day by day for the Anthropogenic Activities. 
Illegal extraction and poaching of wildlife has seriously reduced their potential. Two centuries ago elephant and rhinoceros have been reported in these forests but became extinct in the late nineteenth century. Tigers and leopards were numerous, but tigers dwindled in the early twentieth century and extinct fifty years ago. Leopards are feared to be close to extinction. The Leopard-Cat, Fishing-Cat, Jungle Cat and small Indian Civet are still to be found. The Peacock was at one time quite plentiful but became extinct thirty years ago. Tribal people, Koch and Mandi (garo) are dependent on the Modhupur Tract. In the past thirty years the landscape and ecosystems of most of the Tract has changed drastically. Bengalis has developed stable agro-horticultural systems from Savar to Kaliakair. Urbanisation is extended dramatically in this Tract. Bangladesh Agriculture Research Institute (BARI), Bangladesh Rice Research Institute (BRRI), Bangladesh National University, Bangladesh Open University, Bangladesh Citrus Research Institute, Bangabandhu Agricultural University, etc. are situated in Gizipur. Moreover the government has set up an export processing zone at Ashulia in Savar upazila which is continually expanding.

However illegal extraction and poaching of wildlife has seriously reduced their potential. Two centuries ago elephant and rhinoceros have been reported in these forests but became extinct in the late nineteenth century. Tigers and leopards were numerous, but tigers dwindled in the early twentieth century and extinct fifty years ago. Leopards are feared to be close to extinction. The Leopard-Cat, FishingCat, Jungle Cat and small Indian Civet are still to be found. The Peacock was at one time quite plentiful but became extinct thirty years ago.

Two tribal people, the Koch and the Mandi (garo), who are dependent on these forests, live in the Modhupur Tract. The Kochs are among the earliest people of Bangladesh, while the Mande have their main centre of dispersal in the Garo Hills in India.

\section{Findings in Field Visit to Modhupur Forest}

On October 23, 2010 the team comprising the members of assignment submitter visited Modhupur forest. The visit was one day stay in the forest (areas Jalachatra, telki, Rasulpur) with discussion with local people including people of Garo community, rickshaw/van pullers, and shopkeepers. The findings of discussion with Garo community as perceived by the team are as follow:

\section{Garo Community}

They are Dissatisfied with Government Projects of Exotic Plantation.

People of Garo Community are transforming their Profession from Forest based Gatherers to Common Professions like Rickshaw Pulling, Shop Keeping, etc.

Many people of Garo Community have been Migrated to Different Places of Country for the sake of Livelihood Sustenance.

There is no Properly Documented Land Record System and Land Ownership is based on de facto Land Ownership
System.

Repression against them for Protesting Projects like Eco Park (killing of Choles Ritchil,) created grievance to them.

There is working a Religious Organization which Convincing Non-Muslim Garo People to be Convert to Muslim with Material Benefit. But one Religious Leader of the Organization termed it Resettlement plan for socially displaced people for religion convert.

The findings of discussion with Bengali community people (Rickshaw/van puller) as perceived by the team are as follow:

\section{Bengali Community}

1. Economic pull factor working for coming Bengali people from surrounding area of Modhupur forest.

2. There are presences of forest thieves who are felling trees for timbers.

3. There is growing groups of pirates snatching valuables from tourists.

4. The forest is eroding day by day.

5. There is no major conflict between Garo and Bengali people.

Overall Observation

1. Government agriculture department is working to develop man made rubber plantation in order for economic development. Biological Diversity has been ignored even by the very organization who is supposed to protect and preserve the natural forest.

2. There are depleting image of the forest.

3. There is less presence of wild animals in the forest.

4. There is a Bangladesh Air Force firing Range at Rasulpur inside the forest which is creating threats to wild animals as there are heavy sounds of firing in firing sessions which frightens wild animal and disturbs their reproductive activities.

5. The existence of the forest as there is sight of depletion in every part of the forest.

Biodiversity Depletion in Modhupur Forest in Bangladesh and Their Consequences on Ecosystem Services

Exotic species are damaging to biodiversity of the area and transform the indigenous ecosystem into drought through their increased water uptake characteristics. Moreover, climate change might increase the temperature in this region which infect alters the ecological processes in this tracts. Increased evapo-transpiration causing moisture stress (water deficiency) in winter is affecting the survival of sal forest ecosystem.

\subsection{Case Study: Chokoria Mangrove Forest (Map 8)}

Chokoria Sundarban in a mangrove patch is situated in the southern part of the country. Once it was a habitat of diverse plants and animals but it is completely replaced by brackish shrimp cultivation. The forest was home of tigers, deer's, wild cats, wild boars, foxes etc. These all animals are now rarely seen in the region. The forest was unique with 20 species of trees, some as high as 15 meters. Sundari, Geoa, Keora, Bain were some of the major species. Today the lush 
green vegetation is gone and also gone is the unique, diverse life its environment sustained. In the coastal belt the mangrove forest serves as a shield against cyclones and that tidal surge and gives much-needed protection to the people who live close to the Bay of Bengal. The Chokoria Sundarban provided protection to the people who live in the locality. Today no trees in the Chokoria Sundarbans and no such safety bulb for a few thousand people who live close to the forest that was. Today there is no such forest is seen in that area. The Chokoria Sundarban enriched the local environment with the diverse animal and plant life nurtured. Chokoria Mangrove Forest must be damages within a short period.

This disappearance of Chakoria Sundarban first started in 1929, when British Governments leased out 3910 acres of forests land to 262 local landless families by forming an association of settlers for cooperative cultivation for their subsistence income. That was the beginning of forest clearing activities by human beings (Bangladesh Environment Facing the $21^{\text {st }}$ Century Edited by Philip Gain). Gias Uddin Chawdhuri, a promonent local of Chokoria Sundarban is leased 563 acres land of Chakoria Sundarban in 1977 with a view to establishing Shrimp farm, duck farm and agro fisheries (Bangladesher Biponno Bon by Philip Gain). The major assault on the area came in 1980 when so called development organization has come to develop shrimp firm clearing the forest. The statistics from the Department of Environment reveals that Asian Development Bank took major portion of the forest (around 7000 hectors) land for shrimp cultivation and then it is occupied by the ministry of Land only to perpetuate the development of shrimp firming in the area. The Asian Development Bank begans to fund shrimp cultivation in 1982. Its loan helped set up over a hundred shirmo firms (each eleven acres in size) and build a 16 kilometers embankment. Then came US\$ 26.5 million dollar shrimp culture project funded by the World Bank. The project included a grant from the United Nations Development Program (UNDP). The World Bank's loan [Under Structural Adjustment Program] was used to develop 468 plots (each ten acres in size) and infrastructure (Bangladesh Environment Facing the $21^{\text {st }}$ Century Edited by [10]. By this impractical and unscientific investment of the many authorized organization the disappearance of a most potential forest of Bangladesh is started.

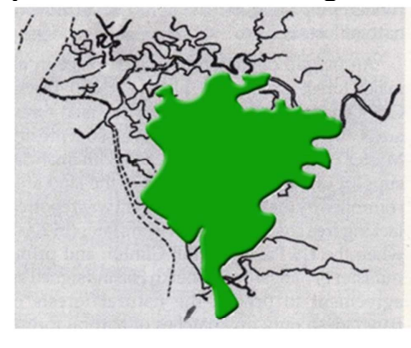

1976

Chokoria $\cdot$ Sundarban-19,617 acres

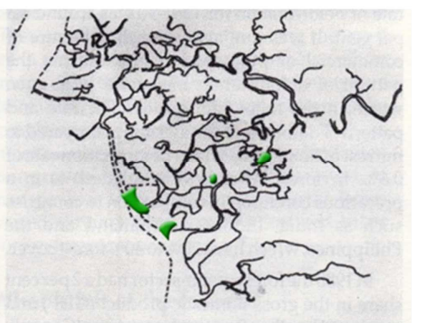

1995

Chokoria $\cdot$ Sundarban-466 acres
Forest'Area

Map 8. Chokoria Sundarban Forest (1976-1995).
Total disappearance of the 21,000 acres Chokoria Mangroves in Cox's Bazar, largely due to Shrimp cultivation, is an example of how shrimp cultivation has caused unprecedented harm to the unique mangrove ecosystem. The unique mangrove patch in the southeast of Bangladesh has lost all but its name today. Thousands prawn farms have replaced almost the entire forest.

Biodiversity deplation on Chokoria Sunderbans Forest and its concequences on ecosystem services:

The Chokoria Sundarbans today- the evergreen forests have been replaced by thousands of shrimp ponds. An ecocide indeed!

Impact on the environment due to the disappearance of natural forest is alarming. Change like Soil turned into salty, human health at risk, animal husbandry appeared tough in want of grazing land, Sea water in absence of forestry often flooded the adjacent area, has abolished the natural ecosystem. Furthermore, natural protection from disaster like SIDR by the forest has been demolished due to the disappearance of the chokoria forest. An attempt has taken to reverse the process by the World Bank but did not stop the degradation. Thus the emergence of development effort has jeopardized the normal dynamics of environment.

\subsection{Case Study: Hilsa Fish (Hilsa ilisa)}

There are many rivers throughout the Bangladesh. Some of them are very potential source of Hilsa Fish. Hilsa is a national fish of Bangladesh and it is very popular over the world. Hilsa gives us both protein and foreign currency. Twelve percent of total fish production of Bangladesh comes from Hilsa. Bangladesh contributes 50-60 percent of world's Hilsa production. Almost 20-25 lac peoples are engaged with the Hilsa production directly or indirectly (Jatio Motso Saptah Sonkolon-2010). It is also known as Hilsa Shad fish. Hilsa or Hilsa Shad fish is now a most cherished treasure of Bangladesh.

May to October is generally considered the hilsa catching season in Bangladesh. But unfortunately the production of Hilsa fish is decreasing day by day for violating the laws imposed with a view to ensuring high production. As a result, dispute and frustration are arising among fishermen and traders in the coastal region.

The prime reason of this crisis is not to have proper implementation of the relevant law. Many fishermen were using current net and catching Jhatca illegally but law enforcement authority did not play their responsibility properly.

According to my visiting experience of Meghnaghat (Chadpur), I went to Meghnaghat (Chadpur) in Mach 2010. Though it was not a seasonal period of Hilsa fish nevertheless a largest amount of hilsa is caught by the fishermen.

However, it is happy news for us that, If the law enforcement authority and other empowered authority are been able to implement the laws related hilsa as it should be done then the production of hilsa will be increased. From the table given above, it is clear to us that after coming the 
government to the power and implementing the laws properly the production of Hilsa are continuously increased.

\subsection{Case Study: Wildlife Consumption and Trade}

Different type of people in Bangladesh used to consume some amount of wildlife species or their products because food, fuel, tibe, fertilizer comes from biodiversity or wildlife species.

Different type of people in Bangladesh used to consume some amount of wildlife species or their products because food, fuel, tibe, fertilizer comes from biodiversity or wildlife species.

Frogs:

The frog legs, live turtles and other biological resources are legally for exported from Bangladesh due to inappropriate policies and guidelines. Most of the frogs used to be harvested from the wild and exported as a frozen food item. As a consequence, the population of some wildlife species has become commercially threatened. To manage this situation the government has forced a ban on trade in wildlife. To control this situation the government has imposed a ban on trade in wildlife without addressing the issue for a long term sustainable management. The frog legs and turtle meats have been allegedly traded under the camouflage of frozen fish/foods even after frequent ban on commercial trade in wildlife.

Frogs have a high demand in the international market. This led the Bangladeshi traders to export frog legs in large quantity until the early eighties. Most of the frogs used to be harvested from the wild and exported as a frozen food item.

Consequences on Ecosystem Services:

Indiscriminately harvest of frogs-main predators in crop fields resulted in enormous use of insecticides in the agriculture fields to control the massive attack of the pests. Uncontrolled harvest of frogs from the wild adversely impacted not only the food-chain, but also had an enormous impact on the population of predators such as monitor lizards, snakes and birds of prey. The environmental activities from home and abroad strongly demanded a ban on frogs collected from the nature. Under pressure of the wildlife scientists and environmental pressure groups, the Bangladesh Government proclaimed some laws to control the trade in frog legs and imposed a ban on the export of frogs. Importing countries of the frog legs from Bangladesh are USA, United Kingdom, Hong Kong, Netherlands, Canada, Belgium, Korea, Bulgaria etc.

Turtles and Tortoises (Geoclenys hamitonil, Melanochelys trijuga)

Turtles, tortoises and terrapins are locally known as Kachim/Kachamp/Kaitta (Batagur baska) Bangladesh supports 25 species of Chelonia of which 18 species are freshwater turtles, five are marine turtles Cuora amboinensis, Geocle,nys hamitonil, Hardella thurjii, Kachuga dhongoka, Kachuga kachuga and two are land tortoises Melanochelys trijuga, Melanochelys tricarinata. Besides their natural ecological role, the Chelonia population in Bangladesh provides meat protein to a percentage of people, especially the ethnic communities. Turtle has been one of the major non-traditional export earners or the country for a long time. Other than use as table food, different byproducts extracted from turtle fats, carapace, plastron and eggs are widely used for treatment, making handicrafts etc. Bostami turtle named after a shrine, Bayezid Bostami in Chittagong is the only endemic wildlife of Bangladesh out of over 1000 species of wildlife so far recorded. This giant turtle (Aspideretes nigricans) is found only in a lone pond of the shrine in Chittagong and nowhere else in the world.

Turtles are considered as religious symbols. According to Hindu mythology, the universe is supported by four elephants standing on a turtle's back. People show special reverence to the turtle as they consider the turtle as one of the ten incarnations of 'Vishnu' the supreme God. River Jamuna, mythological used turtle as her vahan (carriage).

The soft-shell turtles are omnivorous and they are scavengers to the dead bodies of other animals. A huge quantity of turtles is exported from Bangladesh. Turtles are exported mainly to Singapore, Hong-Kong and China from Bangladesh. All the specimens exported are collected from nature. There is no farm for procreating turtles in captivity. Harvesting of turtles from the wild has drastically reduced their population and established their habitats. To save the turtles from going extinct in Bangladesh, the present unsustainable harvest must be stopped and must implementation of biodiversity laws.

Consequences on Ecosystem Services:

Turtles and Tortoises are an important role in the ecosystem of their surroundings as both predator and prey. Mostly they are carnivorous. As an integral component of the food chain they often fulfill the role of 'recycler.' They are also scavengers, feeding on dead and decaying matter. As a result Turtles and Tortoises remove much of the debris from the ecosystem, thereby ensuring that the stored energy can be reused. Sea turtles play an important role in ocean ecosystems by maintaining healthy sea grass beds and coral reefs, providing key habitat for other marine life, helping to balance marine food webs and facilitating nutrient cycling from water to land.

Molluscs in Bangladesh

Subtropical monsoon climate prevails throughout the year in Bangladesh, with the hilly region in the North-Eastern and South-

Eastern part of the country possesses low, flat and fertile flood plains. Ample rainfall and fertile flood plains with rich vegetation as well as the natural rivers, streams, swamps and artificial lakes and water reservoirs offer good habitats for the land and freshwater molluscs. Freshwater gastropods occupy important trophic levels in the aquatic ecosystems. Carnivorous freshwater fishes consume some of the snails. Snails also supplement animal protein for prawn farms, ducks and people of low earning groups, especially the tribal people. On the other hand, certain freshwater snails are the registered intermediate hosts of digenetic trematodes, which cause diseases of man and animals are burning problems throughout the world. People belonging to different tribes in 
Rajshahi, Naogaon, Dinajpur, Chittagong, Rangamati viz, Chakma, Pahan, Orao, Buna, Coch, Garo, Hazong, Khasia, Tripura, Marma, Murang, Pahari, Saontal, Rakhain, Buna are used to consume the different type of snails such as Pila globosa, Bellamya, bengalensis, Lamellidens marginalis etc. regularly to meet up their animal protein requirments. They are used to prepare their curries, with the flesh and viscera of snails in various forms such as ghati, soup, wetfried, fried [33]. A total of 6 species of freshwater mussels under the family Unionidae, order- Unionoida and a slug were collected, which are new records for Bangladesh [34, 35].

At the same time flesh of snails is being expensively utilized in freshwater prawn (Macrodrachium rossenbergii) and the brekish water prawn (Peaneus monodon) culture in south western part and of their region of the country. In addition to that domestic duck poultry, and diffirents cat fishes are also feed with flesh of the snails species. As a result Madaripur, Gopalgonj, Sariatpur, Faridpur, Rajbari, Magura, Norail, Jhenaidoha, Kustia, Chuadanga, Meherpur, Jessore and Bagerhat the significant wetland on south west Bangladesh are under threat of over exploitation area of many kind of snail.

The natural snail populations in the wetland areas of the country are the exclusive source to meet up such high demands. As a result over exploitation without any scientific management of the snail population is causing the bioderversity depletion. A lot of evidences to indicated that the population of the species, P. globosa is decreasing day by day from Bangladesh. Consequently, a study of induced breeding of $P$. globosa was found to be essential in the sense that it may provide information and exploitation of this freshwater resource. In spite of being densely populated Bangladesh possesses vast suitable habitats for freshwater edible molluscs which can supplement the animal protein for the people especially for the lower income group and various types of aquaculture such as prawn farming and cat fish farming.

Consequences on Ecosystem Services:

The snail is an important component of the biodiversity playing vary vital role for the maintenance of the aquatic ecosystem in one hand and on the other hand recently the animal is being utilized as the supplementary feed for prawn, cat fish and poultry farming. It is being eaten by numerous predators, fish, birds and mammals such as various tribal peoples in Bangladesh.

Earthworms: So far knowledge goes till now there is in total 35 species of earthworms have been described by [37] from Bangladesh. Earthworms are widely distributed throughout the world and their population contributes $80 \%$ of the total biomass of the soil ecosystem. They play role to neutralize the soil. The food they ingest, pass through the gut with calcium carbonate particles coated mucus substance by calciferous glands and possibly influence $\mathrm{pH}$ control [38]. Drawida limella, Drawid anepalensis, Glyphidrilus tuberosus, Amynthas alexandri, Lampito mauritii, Metaphire houlleti, Metaphire posthuma, Perionyx excavatus, Perionyx horai, Perionyx modestus, Perionyx simlaensis, Dichogaster modiglianii, Dichogaster saliens, Eutyphoeus gigas, Eutyphoeus orientalis were recorded by [38] in tangail district in Bangladesh.

Gharial (Gavialis ganjeticus) and Crocodile (Crocodylus prosus)

Once this animals were found in the padma, jamuna tista, Mohnanda including Rajshahi area. But now a day it has been very rare. Experts opine that there are only 20-22 pairs of Gharial still exist in our country. But most disappointing news is, even after searching for years all throughout the country, their existence has not been located. Moreover, Crocodile in southern region is not seen as much as it was before.

Why the number is decreasing day by day is sorted out as: i. Smuggle to abroad since its flesh and leather is widely demanded and hence earn a lot of money, ii. Loss of Habitat, iii. Water Pollution, iv. Cleavage of Natural Food Chain, v. Obstacles to normal Reproduction.

Consequences on Ecosystem Services:

Gharial (Gavialis ganjeticus) and Crocodile (Crocodylus prosus) had played a vital role in a river's ecosystem and their presence is important to the environment. They are important components of the food webs in most aquatic ecosystem. They are also filling a critical role both as predator and prey species.

Royal Bengal Tiger (Panthera tigris)

Royal Bengal Tiger is the national animal of Bangladesh. It selects her accommodation considering with mainly food, shelter, risk less, mutual activities facilities etc. Mainly it lives in hilly forest, ever green forest, free forest and mangrove forest through the country. But now, it is not found without sundarbon at anywhere in Bangladesh. It's alive in sundarban with very crisis. Its found also except Bangladesh, in India, Bhutan, Nepal, Myanmar, Indonesia, Malaysia, China and Russia. According to the red list of IUCN, there are 2500 tiger in the world. In Bangladesh, there are 200 but in 2004, in a survey completed by Bangladesh government, the number of tigers is 440 by the conversation with the bearable villager of the sundarbon, the information is given by them, the number tiger is about 200-250. The number of the tiger will be reduce continuously, if we do not take mutual and effective step, to continue and increase also this number of tiger in sundarbon. The causes of reduction of tigers as under follows;

i. weather changing

ii. to increase natural disaster

iii. minimize sweet and maximize salty water

iv. setup new accommodation,

v. Increasing Blakers

Consequences on Ecosystem Services:

Royal Bengal Tiger (Panthera tigris) live in the sunderbans forest ecosystems. They are the top predators in their ecosystems. This means that while they have many prey species, they have no naturally occurring predators.

Top predators control the populations of their prey animals. By feeding on wild deer, for example, tigers keep the deer population within certain boundaries. If the population of 
deer were to exceed these boundaries, overgrazing of vegetation would likely occur.

Mongoose (Herpestes edwards)

These mammals live throughout Bangladesh. It likes to reside beside the paddy fields. It hides in the hole of the bank of the river. There are three kinds of Mongoose But those found more often are smaller in size. These animals preserve the balance of environment and protect crops. Nevertheless, these animals are decreasing gradually. On the other side, it fall prey to the people of the neighboring locality while it tries to catch its prey such as hen, duck, etc.

Killing this animal is increasing at a massive scale. If this continues, this will lead to extinction by short time. Massive killing is committed in the tribal areas in Chittagong, Rajshahi, and Moymensingh.

Eventually it is found after study that the key animals of Bangladesh like Gharial and Crocodile, Kuchia, Snails, Monitor Lizards, Turtles, Tortoises, Frogs, Snails, Monitor Lizards, Turtles, Tortoises, Royal Bengal Tiger, Mongoose etc. which play vital role in our environment are decreasing day by day for lack of appropriate residence, security and necessary food of them. Though there are few laws to protect this massive decreasing of animals but not properly enacted and effective.

Consequences on Ecosystem Services:

Mongooses have a large impact on their prey population, including snakes and rodents. They are important in eliminating rats, mice and especially snakes.

Chronological Reduction of Biodiversity in Bangladesh

From above mentioned case studies it is understood that there are many reasons behind the reduction to endanger, critical endanger, extinct of biodiversity in Bangladesh. The main reasons of them are lack of enforcing laws properly, damaging accommodation, over exploitation, and uncontrolled negative impact in the field of biodiversity throughout Bangladesh.

In water sources, chalan beel displays the causes which are so diverse as to range from the over fishing in the area to the innocuous, protective regulation, unable to deter the people.

Moreover, human beings are dependent on biodiversity for different fundamental demand such as food, cloth, fuel, treatment etc. If the existence of biodiversity is been endangered then the existence of human being will be destroyed. So the protection of biodiversity is highly essential for the interest of human living sound. After that human beings are hunting many useful animals from the natural sources for their unconsciousness. Be short of proper management and sustainable development, natural plants and animals are being lost day by day.

Overall Recommendations for Biodiversity Conservation

The major problem was the sluggish realization of the UN Convention on Biological Diversity (CBD). There is still no adequate data basis for recording the effects of use and overexploitation on biodiversity. Research can make an important contribution here - in monitoring activities and in developing integrated approaches to biodiversity use. Biodiversity can be managed in a sustainable way only if the management plans take proper account of the socio-economic context. It may include a requirement to develop jobs based on the sustainable exploitation of biodiversity.

The Following Suggestions can be made which can Provide Sustainable Biodiversity

i. Biodiversity Rules and Regulations must be Updated and Enforced Strictly. Must be planned to Formulate Appropriate Biodiversity Law and its Competent Implementation.

ii. For sustainable management must be implement traditional knowledge.

iii. The Ministry of Environment and Forestry should have a separate Wildlife Cell or Department.

iv. Human activities often conflict with the conservation of biodiversity.

v. Illegal Capture of Wild Fauna and Aquatic Endangered or Threatened Species must be Stopped and Over Harvesting Stopped.

vi. At least some Major Forest Area, Wetlands and portion of River should be marked as Sanctuary for Bio-diversity Conservation under the Direct Supervision of Government.

vii. Unsustainable development and consumption lead to biodiversity loss and ecosystem damage

viii. Water Pollution by any means should be Minimized and Existing Rules and Regulations on Water Pollution should be Effectively Enforced. Effluent Treatment Plant has to set up to the Outlet of the every Industry.

ix. Use of Pesticide in the Agricultural Fields should be reduced and Biological Control of Pest should be introduced.

x. The Height of Chimney of the Brickfield must by beyond 120ft with a Scrubber in its Outlet. Brickfield must be Established Maintaining a Reasonable Distance and Position.

xi. Cutting Hill in the name of Development and Burning the Trees to cultivate joom is to be prohibited.

xii. Mass Media like Radio, Television, Leaflets and Announcement etc. must be used in Wider Extent for Awareness Building among the Common people about the Consequence of Bio-diversity and its Conservation.

xiii. Appropriate Research and Non-governmental Organizations (NGOs) can play an important role for biodiversity conservation.

\section{Conclusion}

The real effect of biodiversity depletion on ecosystem services is defined by the interactions between genetic diversity and species richness and identity effects in combination with the influence of the environmental context. For future research on the subject of biodiversity- ecosystem functioning, better understanding of the composition of natural food webs and the traits and strength of the interactions among 
species is needed, as well as empirical evidence of how biodiversity loss drivers affect ecosystem function. As long as we ignore the real impacts of human activities on ecosystem services, conservative management policies should be applied in order to minimize the effects of these activities on the remaining biodiversity. Biological resources and biological diversity form the basis of both the ecology and economy of Bangladesh. The country's agriculture, fisheries, and livestock, along with a number of other sectors are heavily depended, directly or indirectly, on biological resources. There is a great potential in Bangladesh for biodiversity-based sustainable development. In spite of threatened wild fauna and flora, there are nearly10,000 species of plants, animals, and microbial organisms - a good percentage of which are found still in abundance. All out efforts are needed to be taken. so that these biological resources are not over-exploited and sustainable management plans need to be formulated and implemented.

\section{References}

[1] Nishat A, Huq SM, Barua ISP, Reza AHMA, Khan ASM. Bioecological Zones of Bangladesh. The World Conservation Union (IUCN), Dhaka, Bangladesh. 2002, 141pp.

[2] Hossain MK. Overview of the forest biodiversity in Bangladesh. In: Assessment, conservation and sustainable use of forest biodiversity (CBD Technical Series no. 3). Secretariat of the Convention on Biological Diversity, Montreal, 2001, 33-35pp.

[3] Islam MM, Amin ASMR, Sarker SK. National Report on Alien Invasive Species of Bangladesh. In: Pallewatta, N., Reaser, J.K. and Gutierrez, A. T. (Eds) Invasive Alien Species in South-Southeast Asia: National Reports \& Directory of Resources. Global Invasive Species Programme, Cape Town, South Africa, 2003, 7-24pp.

[4] IUCN. Red List of Threatened Animals of Bangladesh. The World Conservation Union (IUCN), Dhaka, Bangladesh. 2000, $54 \mathrm{pp}$.

[5] Rahman MM. Forest Resources of Bangladesh with Reference to conservation of biodiversity and wildlife in particular for poverty alleviation. In: Sim, H. C. Appanah, S. and Youn, Y. C. (Eds), Forests for poverty Reduction: opportunities with clean development mechanism, environmental services and biodiversity. Proceedings of the workshop held at Seoul, Korea in 27-29 august 2003. FAO Regional Office for Asia and the Pacific (FAO-RAP), Bangkok. 2004, 139-148pp.

[6] Khan MS, Rahman MM, Ali MA (Eds). Red Data Book of Vascular Plants of Bangladesh. Bangladesh National Herbarium, Dhaka. 2001, 179 pp.

[7] Mukul SA. Biodiversity Conservation Strategies in Bangladesh: the state of protected areas. 2007; 34(3): 28-32.

[8] Bashar MA. Instant Basics of Environment wide approach to nature lover. Positron publication, 38/2/ka, Banglabazar, Dhaka-1000, 2004, 176pp.

[9] Primack BR. Essentials of Conservation Biology Sinauer associate inc. Publisher, sunderland, massachusetts USA 1993, 22pp.
[10] Gain P. Bangladesher Biponna Bon (The Endangered Forest of Bangladesh). Society for Environment and Human Development (SEHD). Lalmatia Dhaka, Bangladesh, 1997, 276pp.

[11] Wilson EO. Biodiversity, National Academy Press, Washington DC 1990, 521pp.

[12] Asmat GMS. Bangladesher Bilupta Bannyaprani (Extinct Wildlife of Bangladesh). Published by Bangla Academy, Dhaka, 2001, 184pp.

[13] Aziz MA, Sultana, S., Begum, S. Bonnyaprani O. Tar Babosthapona (Wildlife and its Management), Kabir publication House, 38/3, Bangla Bazar, Dhaka-1100, 2010, 272pp.

[14] Khan MAR. Bangladesher Bannyaprani. Published byBangla Academy, Dhaka 1996, 148pp.

[15] Paul KN., Sarker MAM. Biodiversity. Eureka Book Agency, New Market, Rajshahi 2001, 244pp.

[16] Karim MA. An Introduction to Environmental Law. Isamoto Prokashoni, 38 Banglabazar, Dhaka-1000, 2004., $79 \mathrm{p}$

[17] Pocock RI. The Fauna of British India, Including Ceylon of Burma. $2^{\text {nd }}$. edn. Memmals.Vols. $1 \& 2$ Taylor of Francis. London 1939, 1941pp.

[18] Husain KZ. An Introduction to the Wildlife of Bangladesh, Dhaka. 1974.

[19] Prater SH. The book of Indian Mammals. $3^{\text {rd }}$. Revised Reprint edn. Bombay, Nat. Hist. Soc. India. 1980.

[20] Khan MAR. Mammals of Bangladesh: A Field Guide. Nazma Reza, Dhaka Bangladesh 1985, 92p.

[21] Khan MAR. Wildlife of Bangladesh: A Check list Dhaka University. Bangladesh, 1982, 173p.

[22] Gazi ASM. Bangladesher Bilupto Bannyaprani (Extinct Wildlife of Bangladesh). Bangla Academy Dhaka. 2001, $184 \mathrm{pp}$.

[23] Gain P. Bangladesh Environment, Facing the $21^{\text {st }}$ Century, Dhaka: Society for Environment and Human Development (SHED), 4/4/1 (B), Lalmatia, Dhaka-1207, Bangladesh 2005, 340pp.

[24] Rahman MR., Asaduzzaman M. Ecology of Sundarban, Bangladesh. J. Sci. Foundation 2010; 8(1\&2): 35-47.

[25] Mannan MA. Environmental Impact Assessment of Development Activities In The Sundarbans. Ph.D. Thesis, University of Rajshahi, Rajshahi, Bangladesh 2012. 423pp.

[26] Kostori FA, Parween S, Islam MN. Availability of Small Indigenous Species (SIS) of Fish in the Chalan Beel: the largest wetland of Bangladesh. Univ. j. zool. Rajshahi Univ. 2011, 30: 67-72.

[27] Samad MA, Galib SM, Flowra FA. Fish Drying in Chalan Beel Areas, Bangladesh. J. Sci. Ind. Res. 2009; 44(4): 461466.

[28] Rahman MR. Wetland Environment of Chalan beel: A Case Study on Singra Beel. J. Environ. Sci. \& Natural Resources 2009; 2(1) 89-95. 
[29] Rahman MR. The Plan for the Chalan Beel Restoration. As a key note paper, Organized by Bangladesh Environmental Lawyer Association (BELA) $21^{\text {st }}$ October 2012, 25pp.

[30] Hamid AM. Chalon Beeler Iti Katha. Magnum Opus, 12, Aziz Supper Market, Shahbag Dhaka, 1967, pp124-143.

[31] Hamid MA. Chalanbiler Eti Katha (A book based on the History of Chalan beel Territory). Published by- Aziz Super Market, Shahbag, Dhaka-1000, Bangladesh 2002, 342pp.

[32] Webster M. Webster`s ninth new collegiate dictionary. Meriam Webster Inc. 1985.

[33] Bhuiyan MMS, Jahan MS, Rahman MR, Haque M. Freshwater Molluscs in the Northeastern Region of Bangladesh. Proceedings of the International Conference on Environmental Technology and Construction Engineering Sustainable Development, ICETCESD-2012, SUST, Sylhet, Bangladesh, pp510-521.

[34] Bhuiyan MMS, Rahman MR, Jahan MS, Haque M. New Record of Some Freshwater Mussels (Bivalvia: Uniodae)
From North-East Bangladesh. Bangladesh J. Zool. 2013, 41(1): 29-42.

[35] Bhuiyan MMS, Rahman MR, Jahan MS, Haque M. Ecology of Slug, (Girasia crocea) (Godwin-Austen) (Stylommatophora : Ariophantidae). J. Environ. Sci. \& Natural Resources, 2013, 6(1): 227-232.

[36] Rahman MR. Environmental Impact Assessment of Sundarbans in Bangladesh. International Journal of Environmental Monitoring and Analysis. doi: 10.11648/j.ijema.20140203.17, 2014, 2(3): 175-184.

[37] Pramanik MN. Annelida. In: Encyclopedia of Flora and Fauna of Bangladesh. Vol. 16 Annelida, Asiatic Society of Bangladesh, Dhaka, 2009, 97-106.

[38] Bahar I, Jahan MS, Rahman MR. Distribution of Earthworms at Different Habitats in Tangail, Bangladesh and Significantly Impacts on Soil pH, Organic Carbonand Nitrogen. American Journal of Life Sciences. Vol. 3, No. 3, 2015, pp. 238-246. doi:10.11648/j.ajls.20150303.26. 